\title{
WestVirginiaUniversity
}

THE RESEARCH REPOSITORY @ WVU

Graduate Theses, Dissertations, and Problem Reports

2005

\section{Lamb and wool production in an organic farming system}

Christopher Kiptanui Ruto

West Virginia University

Follow this and additional works at: https://researchrepository.wvu.edu/etd

\section{Recommended Citation}

Ruto, Christopher Kiptanui, "Lamb and wool production in an organic farming system" (2005). Graduate Theses, Dissertations, and Problem Reports. 2194.

https://researchrepository.wvu.edu/etd/2194

This Thesis is protected by copyright and/or related rights. It has been brought to you by the The Research Repository @ WVU with permission from the rights-holder(s). You are free to use this Thesis in any way that is permitted by the copyright and related rights legislation that applies to your use. For other uses you must obtain permission from the rights-holder(s) directly, unless additional rights are indicated by a Creative Commons license in the record and/ or on the work itself. This Thesis has been accepted for inclusion in WVU Graduate Theses, Dissertations, and Problem Reports collection by an authorized administrator of The Research Repository @ WVU. For more information, please contact researchrepository@mail.wvu.edu. 
Lamb and Wool Production in an Organic Farming System

\title{
Christopher Kiptanui Ruto
}

Thesis submitted to the College of Agriculture, Forestry and Consumer Sciences

at West Virginia University in partial fulfillment of the requirements

for the degree of

\author{
Master of Science \\ In \\ Plant and Soil Sciences
}

\author{
William B. Bryan, Ph.D, Chair \\ Louis M. McDonald, Jr., Ph. D \\ Eugene E. D. Felton, Ph. D
}

\section{Morgantown, West Virginia 2005}
Key words: Compost, herbage mass, pasture management, organic lamb production Christopher Kiptanui Ruto




\section{ABSTRACT \\ Lamb and Wool Production in an Organic Farming System \\ Christopher Kiptanui Ruto}

A study to evaluate lamb production under organic management was carried out in 2003 and 2004 at the West Virginia University Organic Research Farm. About 0.93 ha of tall fescueorchard grass-red clover grassland was assigned to three blocks based on soil type, slope and previous treatment. Each block was divided into two main plots and assigned the following treatments: One was fertilized with compost while the other received no fertilizer. Two groups of sheep under organic management were rotationally grazed on the plots; one group on the plots with compost (high input) and the other on the plots with no compost (low input). The average stocking rate for the low input treatment was $8.6 \mathrm{ewes}^{\bullet} \mathrm{ha}^{-1}$ and 12 lambs $\mathrm{ha}^{-1}$ while the average stocking rate for high input treatment was 10.3 ewes $^{\bullet}$ ha $^{-1}$ and 16 lambs $\bullet$ ha $^{-1}$. Soil fertility parameters, herbage production, lamb production and ewe performance were measured. There was no effect of input on soil $\mathrm{pH}$, soil available $\mathrm{P}, \mathrm{K}, \mathrm{Mg}$ and organic matter. Average lamb production was $327 \mathrm{~kg} \bullet \mathrm{ha}^{-1}$ for low input treatment and $403 \mathrm{~kg} \bullet \mathrm{ha}^{-1}$ for high input treatment. Performance of individual lamb was not different $(P<0.05)$ between the treatments (mean ADG). Lamb production per ha was higher in the high input plots because stocking rate was higher than on the low input plots. Lamb production and performance were lower in 2004 than 2003. This was because of increased parasite infections in 2004. There was no difference in ewe performance and wool production $\left(2.7 \mathrm{~kg} \bullet \mathrm{ewe}^{-1}\right)$ between low input and high input treatments. 


\section{ACKNOWLEDGEMENT}

I sincerely want to thank my advisor Dr. William Bryan for his guidance. I also want to thank the members of the committee; Dr. Louis McDonald and Dr. Gene Felton for the support they accorded me during the study. I also want to acknowledge the Division of Plant and Soil Sciences, West Virginia University for the financial support and the provision of facilities that enabled me carry out the study. My appreciations also go to Dr. Domingo Mata, Dr. James Gekara, Mark Satterfield and the West Virginia University Organic farm crew for all their support in this study. To my family; thanks for the patience. 


\section{TABLE OF CONTENTS}

\begin{tabular}{|c|c|}
\hline & Page \\
\hline ABSTRACT & ii \\
\hline ACKNOWLEDGEMENT & iii \\
\hline LIST OF TABLES & vi \\
\hline LIST OF FIGURES & vii \\
\hline INTRODUCTION & 1 \\
\hline LITERATURE REVIEW & 4 \\
\hline History of Soil Deterioration & 4 \\
\hline Organic Farming & 5 \\
\hline Organic Livestock & 7 \\
\hline Suitability of Sheep in an Organic Farming System & 8 \\
\hline Soil Fertility in an Organic Management & 10 \\
\hline Compost Quality & 12 \\
\hline Organic Fertilizers on Swards & 14 \\
\hline Food Safety and the Use of Organic Fertilizers & 16 \\
\hline Sheep Performance on Pastures & 17 \\
\hline Pasture Suitable For Sheep Grazing and Their Management & 18 \\
\hline Stocking rates And Their Effects on Forages & 19 \\
\hline Effects of Different Organic Fertilizers on Clover Content & 20 \\
\hline Worm Infestation in Organic Sheep Production & 20 \\
\hline ATERIALS AND ME & 23 \\
\hline
\end{tabular}


$\begin{array}{ll}\text { Experimental Site Description } & 23\end{array}$

$\begin{array}{ll}\text { Experimental Procedure } & 23\end{array}$

Management of Sheep, (2003 and 2004) 30

RESULTS AND DISUSSIONS 32

$\begin{array}{ll}\text { Weather } & 32\end{array}$

$\begin{array}{ll}\text { Soil Fertility } & 33\end{array}$

$\begin{array}{ll}\text { Herbage Production } & 36\end{array}$

First cut Hay Production and Botanical Composition 39

Lamb Production $\quad 40$

$\begin{array}{ll}\text { Ewe Performance } & 43\end{array}$

$\begin{array}{ll}\text { CONCLUSION } & 44\end{array}$

$\begin{array}{ll}\text { REFERENCES } & 46\end{array}$ 


\section{LIST OF TABLES}

Table

Page

1. Sheep grazing schedule for $2003 \quad 28$

2. Sheep grazing schedule for $2004 \quad 28$

3. Monthly average daily temperature 33

4. Significance of F-Test for soil fertility parameters 34

5. Soil pH, P, K, Ca, Mg, and OM 34

6. Soil available P levels in high and low inputs 35

7. Effect of useage and input treatment on soil available K 36

8. Herbage consumed, available herbage and residual, per treatment 38

9. Herbage consumed, available herbage, and residual per period 38

10. Effect of input treatment on herbage consumed, available herbage, and residual 39

11. Effect of useage on herbage consumed, available herbage, and residual 39

12. Effect of input treatment on first cutting hay production 40

13. Effect of useage on first cutting hay production 40

14. First cutting hay production on botanical composition for buffer and hay useages $\begin{array}{ll}2003 / 2004 & 40\end{array}$

15. Effect of input treatment on lamb production/ha and weight gain per day 42 


\section{LIST OF FIGURES}

Figure

Page

1. West Virginia University horticulture farm layout

2. The effect of compost and year on soil available P

3. Lamb growth curves for 2003

4. Lamb growth curves for 2004 


\section{CHAPTER 1: INTRODUCTION}

After the Second World War, the human population worldwide has increased at a high rate, threatening to outstrip food resources and deteriorate the environment. The need to produce more food for the increasing population became a concern to researchers. Research work by Norman Borlaug led to the development of high yielding wheat and rice in Mexico, India, the Philippines and China. With these new wheat and rice varieties, grain yields were improved by as much as 98\% (Easterbrook, 1997). Among the major developments in the 1950's and 1960's, an era that was named the Green Revolution, was the development of improved varieties of crops, including cereals that were insensitive to the number of hours of light in a day, making it possible to grow them in many climates. The advancement in plant breeding and the use of synthetic fertilizers and pesticides in the green revolution era saved the world from a Malthusian catastrophe. However, the improved varieties of crops required more fertilizers and pesticides to maintain high productivity. The ever-increasing populations, especially in the developing countries, and the economic growth in the developed countries have led to a higher demand for food and this has led to more use of mineral fertilizers and pesticides. Agricultural production contributes to about $50 \%$ of reported water pollution, mainly in the form of sediment deposition and nutrient loading (National Research Council, 1989). Increased use of synthetic fertilizer and pesticides has led to contamination of drinking water. Confinement of livestock also contributes to nitrates seeping into ground water. Pesticide residues in foods have generated concern in terms of health and the sustainability of an ever-intensifying agriculture system. There has also been a growing trend in many countries in Europe and North America, which practice intensive livestock farming, to extensify their production system by grazing their animals (Pflimlin, et al, 2001). This development is driven mainly by society's expectations for a healthly food supply. 
Consumers are also concerned about conditions of production, for example, animal welfare and the effect of the production system on environmental quality; i.e, aquatic life and contamination of ground water.

The organic agriculture movement in major industrialized nations began in the 1930's as an alternative to increasing intensification of agriculture, especially the use of synthetic N. Goals of organic farming include the management of resources in a self-sustaining manner without chemical inputs and the linking of agriculture and nature (Kyle, 2004). According to the Economic Research Service (2004) report some of the reasons that motivate farmers to change to organic methods include the need to conserve non-renewable resources, the opportunity to lower inputs costs and the attractive prices for organic produce. On the other hand, consumers of organic products are motivated by the belief that organic products are healthier than conventional products, tastier and more environmentally friendly.

Most of the world's grassland ecosystems are situated in fragile environments that are not suitable for intensive exploitation. These areas are characterized by arid and semi arid conditions and shallow soils that are prone to erosion; therefore there is need for farmers, researchers and economists to combine production and environmental protection (FAO, 2004). Managing these grasslands organically is one of the options. Organic management of grasslands maintains the ecosystem, adds value to its products (milk, meat, wool), and can provide adequate income adequate for farmers (FAO, 2004).

West Virginia is one of the States that lie within the Appalachian region. The region is characterized by hilly terrain and shallow soils. These features are not conducive for intensive cultivation and, consequently, most of the non-forested land is used for grazing by both livestock 
and wild game. West Virginia's climate can sustain good herbage growth of high quality. Farmers in this region can produce grass-based beef, lamb, wool and poultry.

The market for lamb is continually expanding in the U.S.A. The reasons for this expansion include immigration from countries where lamb is commonly eaten and the increasing Islamic population, which uses lamb in most of its religious celebrations (Qubain, 1994). Although sheep can use natural vegetation in mountainous areas, such as West Virginia, the rate of adoption of organic practices for grassland by producers is low (0.25\% for 2001). Among the constraints to adoption pointed out by farmers are the high managerial input requirements required in an organic farming system, the risks involved in shifting from conventional to organic farming, the lack of markets and infrastructure and limited knowledge and awareness of organic farming systems (Economic Research Service, 2004). Challenges faced by organic producers include control of parasites in organically raised livestock, control of weeds and maintaining adequate plant nutrients.

The objectives of this study are (1) to determine herbage accumulation and seasonal distribution of tall fescue, orchard grass and clover grassland with and without compost when managed for lamb and wool production, (2) to determine the effect of compost application on soil $\mathrm{pH}$, organic matter and available $\mathrm{P}, \mathrm{K}, \mathrm{Ca}$ and $\mathrm{Mg}$, and (3) to compare production of organic lamb and wool on grassland with and without compost. 


\section{CHAPTER 2: LITERATURE REVIEW}

\section{History of Soil Deterioration}

Our early ancestors depended indirectly on soil for their food by gathering and hunting in the forest. However, after transition to agriculture, about 11,000 years ago, farmers in South East Asia and elsewhere started depleting soil nutrients by continuously cultivating the land. However, when these farmers learned to keep cattle, sheep and goats the soil was enriched. These animals would be kept mostly on non-arable land and their dung collected and spread on cropland. Humans and animals lived on land that sustained them and the loss of nutrients from the system was negligible.

Urbanization took place about 5000 years ago. Many people moved to cities where there was no farming. As a result, food was exported from the farms to these cities and this meant that nutrients moved out of the farming system to cities where they were eventually lost to streams and lakes. As the cities increased, the loss of nutrients also increased. This posed a big challenge to farming. Farmers started opening up more land for agriculture and soil erosion became rampant.

Agriculture causes soil erosion at different magnitudes but globally soil erosion was significantly accelerated during three eras. The first era occurred in the second millennium B.C.E. when the population of the early river basin civilizations increased. These civilizations began to exploit the nearby forested slopes, resulting in erosion. The second period of accelerated erosion took place between the $16^{\text {th }}$ and the $19^{\text {th }}$ century when Europeans migrated to America, Australia, South Africa, etc. These immigrants ploughed land, most of it under different climatic and ecological conditions from what they were used to, causing accelerated erosion. After the Second World War, advances in medicine allowed human population to 
increase. Encroachment of rain forests then took place and land on steep slopes was cultivated to meet food needs (McNeill and Winiwarter, 2004).

Synthetic N became readily available in 1913 with the discovery of the Haber-Bosch N fixation process. This synthetic $\mathrm{N}$ production reduced the cost of transportation and application by about 20 fold compared to organic sources. However, a major feature of this process is the separation of $\mathrm{N}$ from organic $\mathrm{C}$ and its affect on soil microbes that depend on organic $\mathrm{C}$ for their energy needs. Continuous use of synthetic fertilizers reduces microbial populations and their contributions to soil fertility are greatly reduced (Lotter, 2001).

\section{Organic Farming}

Organic agriculture in major industrialized nations began in the 1930's as an alternative to intensification of agriculture, especially the use of synthetic N. Northbourne first used the word "organic farming" in 1940. Organic farming refers not only to the use of organic materials for soil fertility management but includes management of the farm as an organic or whole system that integrates soil, crops, animals and society (Lotter, 2001).

Organic agriculture, according to Lotter (2001), can be defined as an ecological production management system that promotes and enhances biodiversity, biological cycles and soil biological activity. Organic farming is defined as a farming system that includes rational use of organic manure, appropriate cultivation techniques, the avoidance of soluble fertilizers, the prohibition of agrochemical pesticides and the use of balanced rotations (Philipps, 2001). The term "organic" should not be limited to the type of inputs only but should include the concept of the farm as a living organism with soil minerals, organic matter, micro organisms, insects, plants and animals interacting to create a sustainable, natural resource (Richardson and Scholar, 1997). 
Globally, 130 countries, including the USA, produce certified organic products in commercial quantities (Lotter, 2001). The countries that farm organically include Switzerland with $9 \%$ of its farmland under organic management, Austria with $8.6 \%$, Italy $6.8 \%$, Sweden $5.2 \%$, the Czech republic 3.9\% and the UK with 3\% under organic management (Greene and Kremen, 2003). In 2001, about 1.3 million acres of cropland and 1.0 million acres of pasture in the USA were under organic production. California, North Dakota, Minnesota, Wisconsin, Iowa, Montana and Colorado had the highest acreage under cropland while Texas, Colorado and Montana had the largest amount of land under pasture (Economic Research Service, 2004).

In the USA, organic farming is one of the fastest growing sectors of agriculture since the 1980 's maintaining an average of $20 \%$ growth per year (Lipson, 1997). According to Lipson (1997) there were about 10,000 farms that engaged in profitable, agronomically successful, commercial organic production. These farms were spread all over the USA and every crop grown in the USA was represented. Certified organic pastures and rangeland increased more than two fold from 1997 to 2001. By 2001, it was estimated that organic crop and pastureland amounted to $0.3 \%$ of US crop and pasture land. Over 40 states had certified pasture and rangeland in 2001 with the average per state ranging from under 20,000 acres in most of the states to over 500,000 acres in Colorado (Greene and Kremen, 2003).

A study carried out by the Organic Monitor showed that the American Continent now surpasses Europe as the leading market for organic foods and beverages. Lotter (2001) estimated the global organic products market at 20 billion dollars in 2001. In the US, organic products amounted to about $2 \%$ of total food sales (Lotter, 2001) and this was estimated at 9 billion dollars (Rich, 2003) while the range was 1 to 5\% in most countries in Europe. The study showed 
that American consumers pay a premium price of between 20 to $400 \%$ more for organics than for conventionally produced products (Delate, 2003).

\section{Organic Livestock}

Livestock or livestock products that are sold as organic must be raised using organically grown feeds. The area used to produce feed should not have been treated with synthetic fertilizers and pesticides for at least 3 years. For ruminants, the bulk of the feed should come from forages. No transgenic (GMO) foodstuff and animal by-products are permitted in organic livestock production. The use of animal by-products as animal feed has been linked to mad cow disease (BSE). On the health side, materials banned in organic livestock production include antibiotics, growth hormones, synthetic de-wormers and medicated feed additives (Kyle, 2004). Organic livestock are to be kept under their natural environment as much as possible to enable them to exhibit their natural behavior ( Kumm, 2002). An experiment carried out in Sweden suggested that organic lamb and beef production is feasible. Organic livestock production, however, required more land (Kumm, 2002).

The increase in land hectarage under organic farming is due to the world wide consumer awareness of the food they eat, their health, the environment and sustainability issues. Consumer demand for organic products also increased because of the food scares of the mid to late 1990's. These scares, that included BSE disease incidences, made consumers question the safety of their

food and purchases of organic products increased (Richardson, 1999). Organic meat accounted for $3 \%$ of total organic sales in 2000 . Other benefits of organic farming include improvement of soil tilth and productivity and lower energy use (Greene and Kremen, 2003). 


\section{Suitability of Sheep in Organic Farming System}

Domestication of sheep is thought to have taken place about 11,000 years ago. Since then, man has grazed sheep on arid lands and natural vegetation on hilly and mountainous areas to produce meat, wool and milk. Forages alone can produce a USDA choice carcass (Umberger, 2001). Sheep are $26 \%$ more efficient than cattle in converting forages into useful products (Outhouse, 2004). Because sheep are good grazers, less use of fossil energy is required to produce them than animals fed on grain and stored forages (Outhouse, 2004). Sheep can graze on hillsides and steep slopes, increasing soil fertility and forage use on these areas (Umberger, 2001). Sheep spread their feces more uniformly than cattle. Sheep production requires relatively low capital investment, is flexible and can be easily integrated with crops. Sheep utilize crop residues and weeds (Ely, 1994). Sheep can be grazed with other species of livestock such as cattle and goats leading to better use of the grassland compared to when only one species is used (Umberger, 2001). They can eat plants poisonous to other grazers (Ely, 1994). Sheep are compatible with agronomic practices that require some of the arable land to be sown to grass leys to control soil erosion and to conserve water (Oltjen and Beckett, 1996). By using sheep to graze along perimeter fence lines, under fruit trees and to scavenge on cropped areas, the need for herbicides is reduced. Sheep can consume up to $90 \%$ of the weeds in grassland (Outhouse, 2004).

Ely (1994) reported that lamb production from rangeland required the lowest inputs in terms of machinery, herbicides, pesticides and transportation compared to any other livestock production system. Ewes are able to produce $150 \%$ or more of their body weight in offspring per year compared to cattle that can produce only about 60\% (Ely, 1994). Rumen bacteria require

less $\mathrm{N}$ than $\mathrm{N}$ required by plants for maximum yield. A CP concentration in the dry matter of 
over $7 \%$ is adequate for many animals and a higher concentration may not improve digestibility and intake (Ely, 1994). Since sheep obtain most of their N from rumen microbial protein, the use of $\mathrm{N}$ fertilizer to maximize forage yield may be wasteful because $\mathrm{N}$ accumulation in the forages will be more than the rumen microbial requirement (Ely, 1994). Incorporation of legumes into grasslands for lamb and wool production is an alternative to reduce costs.

Plants in sheep grazed swards re-grew faster and accumulated more herbage more quickly than on cattle grazed areas (Murphy, et al, 1995). Areas grazed by sheep also showed an increase in soil fertility compared to cattle grazed areas. This difference may have been due to the difference between sheep and cattle in manure distribution and soil compaction. Sheep distributed their dung and urine uniformly while cattle concentrated their dung, forming patches. Soil nematodes and rotifers per $100 \mathrm{~g}$ of soil were higher on sheep grazed than cattle grazed pastures.

Marriott and Gordon (1990) tested the effect of extensifying sheep production on soil, plant and animal. They found no difference in soil variables after 4 years of not using fertilizers. They estimated that 60 to $90 \%$ of nutrients ingested in herbage were returned to the soil in dung and urine. They also found little change in botanical composition over time on grazed plots but preferred species receded on non-grazed non-fertilized plots. The number of grazing days did not decrease for over five years, suggesting that the high clover content fixed $\mathrm{N}$ and maintained good herbage growth. It was also observed that individual lamb performance was less on the unfertilized treatment compared to the fertilized treatment. 


\section{Soil Fertility under Organic Management}

The most common soil amendments used in organic farming systems include compost, manures (cattle, sheep, poultry and pig) and rarely, biosolids. Compost is the most economical pre-plant organic nitrogen source while other organic fertilizers are more fitting for side dressing (Gaskell, 1999). Composting is normally done in windrows, turned periodically (once a week on most farms) and is usually ready for use in 6 to 8 weeks (Killen, 2000). Green manure is also common on cropland. Accurate estimates of plant available N, timing, application method and even spreading are crucial not only to ensure that plant nutrients are adequate but also to reduce surface and ground water pollution (Evanylo, 2004). According to Evanylo (2004), 60\% of the N in digested biosolids and unbedded manure is organic while it is close to $100 \%$ in lime stabilized biosolids, heavily bedded litter and composted wastes. Estimation of mineralization rate of manures is important in calculating $\mathrm{N}$ application rates. Mineralization rate depends on $\mathrm{C}: \mathrm{N}$ ratio, weather and soil type. In the mid Atlantic region, lime stabilized and digested biosolids mineralize at the rate of 30 to $35 \%$ during the season of application. Cattle (dairy and beef) manure mineralizes at 35 to $45 \%$ in the season of application while swine and poultry manure mineralize at the rate of 40 to $50 \%$ and 50 to $70 \%$ respectively (Evanylo, 2004).

An experiment examined the availability and transformation of $\mathrm{P}$ in soil treated yearly with manure for 20 years. Soils ranged from well drained to poorly drained. Manure application increased $\mathrm{P}$ and most of the $\mathrm{P}$ remained within 0 to $30 \mathrm{~cm}$ of the soil surface with some moving downwards. The trial also showed accumulation of $\mathrm{P}$ in the organic matter of poorly drained soil. Poorly drained soil had less extractable $\mathrm{P}$ than well-drained soil. This finding suggests that selection of soil for manure application or disposal is important for better recycling of $\mathrm{P}$ (Kuo and Baker, 1982). 
A study was carried out by the American Society of Agricultural Engineers to examine nutrient content of manures. This work involved analysis of manures from feedlot, dairy barn and pigsty and showed that annual application of these manures in the right amounts provided all major plant nutrients. The trial also concluded that manures provide trace elements in adequate quantities not normally added with application of commercial fertilizer (Arrington and Pachek 1981). However, Mader, et al (2002) indicated that the inputs of N, P and K, were about 34 to $51 \%$ lower in an organic farming system than in a conventional farming system but the mean reduction in yield of crops was only $20 \%$ over a period of 21 years, suggesting that the organic farming system was more efficient in the use of resources. For individual crops, potato yields under the organic system were 58 to $66 \%$ of those of the conventional system. Low K content in organic fertilizers and high incidences of Pytophthora $s p$ infestations were suggested as the major reasons for the low yields. In Europe, mean cereal yields under an organic farming system ranged from 60 to $70 \%$ of the conventional yields whereas grassland yields were 70 to $100 \%$ of the conventional (Mader, et al, 2002). Killeen (2000) also reported that different crops responded differently to composted manure and that crops respond differently to different sources of manure. According to this report, beetroot responded well to goat manure compost and dairy compost manure but carrots responded most strongly to goat manure.

Vetter and Klasink (1972) indicated that pig and poultry slurry were 2.5 to $15 \%$ and 7.5 to $30 \%$ in DM content respectively and that pig slurry had about 4 to 5 times more $\mathrm{Cu}$ than poultry slurry, while poultry slurry had more $\mathrm{CaCO}_{3}$. They cautioned that long-term application of slurries at high rates might lead to a decrease in soil fertility despite an increase in plant nutrients. Residual effects of manures or compost can last several years because only a fraction of the manure or compost is available during the year of application. A study to evaluate the 
residual effects of annual or biannual application of $\mathrm{N}$ based or $\mathrm{P}$ based composted or non composted beef cattle manure showed that residual effect lasted at least one growing season, resulting in about $89 \%$ of the corn yield of chemical fertilizer. However, the residual effects of this compost on soil properties lasted longer than effects on corn production. Soil P, pH, EC and $\mathrm{NO}_{3}$ were higher 4 years after the last application of compost/manure than after inorganic $\mathrm{N}$ fertilizer application (Eghball, et al, 2004).

Other strategies used by farmers practising sustainable agriculture and organic methods include crop rotation, planting of cover crops, legumes, light cultivation to control weeds, diversification of crops, integration of livestock and crops and intensive grazing. Maintaining a good cover of white clover can fix 150 to $200 \mathrm{~kg}$ per ha of atmospheric N per year (Outhouse, 2004). A rich clover upland sward can produce about $80 \%$ of the herbage mass of highly fertilized grassland (Keatinge, 2004). Mowing can be used with rotational grazing to control weeds (Outhouse, 2004).

\section{Compost Quality}

Compost is a product of biological degradation of organic solid waste that has undergone an initial rapid stage of decomposition and is in the process of humification (Tyler, et al, 1994). Compost is a dark brown material whose initial constituents cannot be recognized and further degradation is not noticeable (Mangan, et al, 2000). The process of composting can take a few weeks to over a year depending on various factors that include the nutrient balance (in terms of C: $\mathrm{N}$ ratio) the feedstock, moisture content, temperature and aeration (Buckley, 2004).

Quality of compost is normally determined when the composting process is complete. However, Tyler et al (1994) classified compost feedstock into three types to assist in designing 
the testing regime. Type 1 includes wood waste, separated from yard wood wastes, agricultural crop residues, manure from herbivores, pre consumer meat free food wastes and other materials that are considered low in hazardous materials according to the Jurisdiction of Health Departments (JHD). Type 2 includes biosolids, meat and post consumer source separated food wastes and waste from other similar sources. This type is considered by the JHD to be low in hazardous materials and physical contaminants but could harbor high levels of human pathogens. Type 3 includes mixed municipal wastes; post collection separated or processed solid wastes, industrial biological treated sludge and other similar materials. This type is considered to have relatively high amounts of hazardous materials, human pathogens and/or physical contaminants. Type 1 feedstock is common on farms and gardens. Tests on this category of compost normally include $\mathrm{pH}$, and $\mathrm{Pb}, \mathrm{Cd}$, ammonia, nitrate, and Kjeldahl $\mathrm{N}$. The last three parameters show the agronomic value of the compost (Tyler, et al, 1994). Other parameters of interest to compost users include compost maturity, salt content, presence of weed seeds and physical and chemical contaminants. According to Buckley (2004) a well-composted material is odorless, fine-textured, and low in moisture and does not attract flies. Mature composted dairy cattle manure is expected to have 0.3 to $0.6 \% \mathrm{~N}, 0.1$ to $0.2 \% \mathrm{P}, 75$ to $90 \%$ water, a $\mathrm{C}$ : $\mathrm{N}$ ratio from $8: 1$ to $30: 1$ and a $\mathrm{pH}$ of 6 to 8.

Immature and unstable compost can cause detrimental effects to plants. Continued decomposition of immature compost draws oxygen and nitrogen from its surroundings thus affecting plant growth negatively. Immature compost may also contain phytotoxins (Mark, et al, 2004). The amount of soluble salts is not very important in compost that is to be spread in the field but should be considered for compost that is destined for greenhouse mixes (Mangan, et al, 2004). In the field the ratio of soil to compost is so high that the effect of added salt is 
negligible. However, in greenhouse mixes, the ratio of soil to compost is low and the effect of soluble salts can be significant. Because compost is not a good source of $\mathrm{N}, \mathrm{P}$ and $\mathrm{K}$ a new method of determining the quality of compost based on microbial content is being developed. Organisms of importance include aerobic bacteria, anaerobic bacteria, fungi, actinomycetes, Pseudomonas and nitrogen fixing bacteria (Buckley, 2004)). The bedding materials used affect the quality of compost. Wood based materials produce fungus-dominated compost while straw favors bacteria. Too much rain lowers the quality of exposed compost.

\section{Organic Fertilizers on Swards}

A field trial carried out in France in 1977/78 showed no significant difference in herbage mass, live weight gain of bullocks, or mineral composition of forages but the percentage of palatable grasses in the swards increased from 20.9 to $38.1 \%$ in plots that received cattle slurry while plots that received mineral fertilizer had $32.8 \%$ palatable grasses. Cattle slurry increased the proportion of perennial ryegrass, timothy and fescue while reducing that of cocksfoot, Holcus lanatus and Alopecurus pratensis with no effect on persistence of legumes (Laissus and Leconte, 1982). Observation after 30-year use of manure in Ukraine showed an increase in soil humus, N, $\mathrm{P}$ and $\mathrm{K}$, soil aggregation and absorption capacity. There was a decrease in soil acidity and density (Gorodnii, 1964). While continued use of mineral fertilizer initially led to higher yields of cotton and other crops compared to the equivalent of manure $\left(40 \mathrm{t}^{\mathrm{h}} \mathrm{ha}^{-1}\right)$ manure was more effective than mineral fertilizer during the subsequent years, showing increased yield and quality of cotton (Gorodnii, 1964). Cattle slurry increased the initial relative herbage growth rate in spring but this increase was less pronounced in regrowth. The growth response due to cattle slurry application was high in early spring but as clover content increased, the effect of slurry on 
growth rate was reduced. The highest growth rate was achieved at $55 \%$ clover content during spring while regrowth rate increased linearly with the amount of clover present. Cattle slurry reduced clover dry matter yield by $7 \%$ in spring growth and by $13 \%$ in regrowth (Steinshamn, 2001). An experiment comparing the effect of $\mathrm{N}$ from cattle slurry and mineral fertilizer indicated that $\mathrm{N}$ from both cattle slurry and mineral fertilizer depressed clover content of the grassland but to a lesser extent with slurry than mineral N (Nesheim, et al, 1990). In Austria, Steinwender, et al (2000) found little difference between organic forages (fertilized by cattle slurry) and conventional forages (fertilized by mineral $\mathrm{N}$ ) in terms of nutrient and mineral content. They concluded that organic farming produced forages similar in nutritional value to those produced conventionally but herbage mass was lower because $\mathrm{N}$ was limiting. They estimated that herbage accumulation from the organic farming system was $2000 \mathrm{~kg} \bullet \mathrm{ha}^{-1}$ less and as a consequence, the stocking rate was lower.

Work by Benkov (1964) showed that sheep dung applied at a rate of $25 \mathrm{t} \mathrm{ha}^{-1}$ increased average green matter yield by $65 \%$ while the increase in hay was $55 \%$. When the rate of dung application was increased to $35 \mathrm{t}^{\bullet} \mathrm{ha}^{-1}$ the increase in green matter yield was $90 \%$ while hay yield increased by $78 \%$.

Weller and Cooper (2002) examined CP concentrations in a white clover/perennial ryegrass sward grazed by dairy cattle. They found that CP concentration of clover increased during the grazing season with a mean of $251.6 \mathrm{~g} \cdot \mathrm{kg}^{-1}$ in the first year and $271.9 \mathrm{~g} \mathrm{~kg}^{-1}$ in the second year. Within the same period, ryegrass CP concentration increased from $151.9 \mathrm{~g} \mathrm{~kg}^{-1}$ to $174.0 \mathrm{~g}^{\bullet} \mathrm{kg}^{-1}$. The results suggested that maintaining optimum clover content in a sward is important, especially in an organic grassland system because the legume is the main source of $\mathrm{N}$ with a potential of fixing 150 to $200 \mathrm{~kg} \mathrm{~N} \bullet \mathrm{ha}^{0^{-1}} \mathrm{year}^{-1}$. 


\section{Food safety and The Use of Organic Fertilizers}

Avery (1998) raised concern that the use of manure as a soil amendment may lead to the presence of dangerous pathogens on organic produce but was refuted by Burros (1999). Manure may carry pathogens that cause diseases in humans and animals. The most important pathogens include Campylobacter jejuni, Yersinia enterocolitica, Cryptosporidium spp. and the recently identified E. coli 0157:H7 that causes severe illness in humans. These pathogens are transmitted by contamination of food with feces. Other sources of infection include juices and uncooked greens such as lettuce, sprouts and mushrooms (Olson, 2004). Storing manure as slurry, solid or compost reduces these pathogens. E. coli $0157: \mathrm{H} 7$ does not increase in cattle grazing on manure fertilized grassland indicating that it does not survive for long periods after manure is spread (Kirk, 2004). E. coli in manure, according to Pell (1997), is destroyed within 35 to 56 days during composting. As a precaution, the USDA's protocol recommends that at least 120 days pass from the time of manure application to harvesting of the crop (Agricultural Marketing Service, 2000).

A study was carried out for 8 years to determine total bacterial content, coliform bacteria, salmonella, clostridium, fungi, anthrax, total vegetable and animal material in horn meal, bone meal and poultry manure used as organic fertilizer. The results indicated that the presence of these organisms was very low. Only one case of salmonella was found in one sample (Strauch, et al, 1982).

A study of the movement of microorganisms such as E. coli (bacteria), Salmonella (bacteria) and Cryptosporidium parvum (protozoa) indicated that grass strips filtered 90\% of these manure borne pathogens from runoff (Durham, 2002). The pathogen count in the runoff collected from bare ground had almost no reduction. Pathogens that remained in the soil were 
consumed by other organisms or settled between soil particles. These organisms would die before contaminating food and water supplies (Durham, 2002).

\section{Sheep Performance on Pastures}

Even under conventional production, lamb weight gain is not uniform throughout the grazing season. In spring, lambs gain about $273 \mathrm{~g} \bullet$ day $^{-1}$ while they gain about $136 \mathrm{~g}$ day $^{-1}$ between July and August and about $182 \mathrm{~g} \bullet$ day $^{-1}$ in fall (Umberger,2001). Daily weight gains, however, can be adversely affected by internal parasites. Live weight gain of weaned lambs grazing tightly on perennial ryegrass and short rotation ryegrass was more than when they grazed lightly on the same grassland. The same trend was observed in lambs grazing on timothy/white clover/red clover grassland. The main reason for this observation was the deterioration of lightly grazed swards in late summer and autumn (Lewis and Cullen, 1973).

Rotational grazing produced more herbage mass than set stocking (Warner and Sharrow, 1984; Currl and Wilkins, 1981). However, Warner also found that weight gains of lambs under rotational grazing were superior to those of set stocked lambs only when herbage allowance was low, otherwise there was no difference between the two managements. Generally, high stocking rates have been shown to lower performance per animal but increase production per unit area (Suckling; 1975, Currl, et al, 1985).

Summer and spring stocking rates have more effect on wool production than winter feeding. Higher levels of feeding in summer (lower stocking rate) had more effect on wool production than feeding above maintenance level in winter (Davis, 1975). In Australia, two groups of sheep were grazed on Phalaris tuberosa/Trifolium repens grassland for a period of one

year at two stocking rates ( 8.6 or 17.3 per ha) and the results indicated that live weight gains of 
ewes and rate of wool growth decreased during lactation but improved after weaning, being lowest for the high stocked group. Lambing percentage was 115\% for the low stocked group and $71 \%$ for the high stocked group (Corbet and Furnival, 1976).

\section{Pastures Suitable for Sheep Grazing and Their Management}

Among the most common grasses used for sheep are Kentucky bluegrass, tall fescue, orchard grass, and bromegrass. Clovers, alfalfa and birdsfoot trefoil are common legumes that are normally mixed with grasses and usually not grazed alone because they can cause bloat (Outhouse, 2004). Outhouse (2004) states that tall fescue, common in some temperate grasslands including West Virginia, is suitable for grazing in winter, from December to March. A two-year study carried out at Purdue University indicated that ewes grazing on tall fescue, plus 227 to 341 $\mathrm{g} \bullet$ day $^{-1}$ of shelled corn as a supplement for 70 to 84 days before lambing in March, performed as well as ewes on alfalfa haylage in dry lot. The observed performance was also the same as that of ewes grazing on tall fescue supplemented with $455 \mathrm{~g} \cdot$ day $^{-1}$ of haylage, but the cost of fescue pasture with corn supplement was 30 to $50 \%$ lower. Another advantage of tall fescue was that it developed a sod dense enough to support the weight of ewes under wet conditions (Outhouse, 2004). Outhouse's recommendations on the use of tall fescue include; grazing spring growth with ewes and lambs (May-June), baling second growth (June-July), and fertilizing the grassland with $23 \mathrm{~kg} \cdot \mathrm{ha}^{-1}$ of $\mathrm{N}$ in late August to stimulate fall growth and winter grazing, scheduled to start in early December. 


\section{Stocking Rates and Their Effects on Forages}

At stocking rates of 61 and 74 sheep $\mathrm{ha}^{-1}$ from May to October, perennial ryegrass/white clover grassland produced herbage mass accumulations of 5,420 and $8,990 \mathrm{~kg} \bullet \mathrm{ha}^{-1}$ from the grazed area for high and low stocking rates respectively. Treading reduced herbage mass by $10 \%$ at the high stocking rate and by $4 \%$ at the low stocking rate. This experiment also indicated that excreta return increased herbage production by 53 and $26 \%$ for the high and low stocking rate, respectively. In autumn, clover content increased from 58 to $71 \%$ on treatments that had no excreta return while clover was reduced by $45 \%$ on treatments that had excreta return. By autumn the high stocking rate had increased clover content in the grazed area by $31 \%$, by $25 \%$ in the trodden area and by 18\% where excreta was returned (Currl and Wilkins, 1981). Application of cattle slurry reduced clover dry matter production by $7 \%$ in spring and by $13 \%$ in the regrowth (Currl, et al, 1985). The decrease was attributed to an increase of ryegrass. Ewes on a low forage allowance (high stocking rate) ate less herbage, produced less milk and lost more weight than those on a high allowance. Lambs on the low allowance were lighter at weaning than lambs on the high allowance, but after 17 weeks, they grew faster and by 25 weeks they were the same weight as those from the high allowance group. On average, the stocking rate of organically managed systems in Wales is $25 \%$ lower than conventional systems (Philipps, 2001). Increasing the stocking rate of an organic system to about the stocking rate of a conventional system in an attempt to increase profitability may affect animal performance (Keatinge, 2004). 


\section{Effects of Different Organic Fertilizers on Clover Content}

Work by Steinshamn (2001) on the application of cattle slurry to grass-clover grassland indicated that it increased initial forage growth rate by 0.21 to $0.23 \mathrm{~g}^{\bullet} \mathrm{day}^{-1}$ in spring but the regrowth was relatively slow. The experiment showed that a high proportion of clover increased the growth potential of the grassland both in spring and in the regrowth thereafter. Clover increased on treatments that received no manure but decreased on treatments to which manure was applied.

A four-year trial on the effect of cattle slurry and mineral fertilizer on nitrogen fixation showed that $\mathrm{N}$ obtained from symbiotic bacteria was $90 \%$ of total soil $\mathrm{N}$ in the unfertilized treatments. Data from two harvests indicated that $51.2 \mathrm{~kg} \mathrm{~N} \bullet \mathrm{ha}^{-1}$ was fixed in the absence of $\mathrm{N}$ fertilization but when $75 \mathrm{~kg}$ mineral $\mathrm{N} \bullet \mathrm{ha}^{-1}$ or $50 \mathrm{~m}^{3}$ cattle slurry $\mathrm{ha}^{-1}$ was used, the amount of

$\mathrm{N}$ fixed fell to 17.2 and $24.9 \mathrm{~kg} \bullet$ ha, ${ }^{-1}$ respectively, showing that cattle slurry depressed clover content to a lesser extent than mineral $\mathrm{N}$ fertilizer at this application rate.

Murzynski (1971) indicated that mineral fertilizer reduced complexity of botanical composition in both hay and pasture areas. Work by Benkov (1964) in Bulgaria on spring application of sheep dung showed that legume proportion was reduced from the initial 3 to $12 \%$ in the first three years to $2 \%$ in following years.

\section{Worm Infestation in Organic Sheep Production}

Internal parasites, especially roundworms, cause production losses in sheep. They reduce feed intake, damage gut lining, lead to loss of endogenous protein, reduce growth rate and can cause death (Howells and Marley, 2001). The effect of worm infestation is greater on young stock because they are more susceptible. The use of synthetic antihelminthic drugs to control 
strongyles and cestodes is prohibited under organic management, making worm control a major concern (Cabaret, 2002). In an organic livestock production system, the intensity (numbers) and diversity (number of species) of worms is high (Cabaret, 2002), with gastrointestinal nematodes, flukes and Monieza cestodes being the most important. Conversion from a conventional to an organic system affects lamb production more than dairy cattle production.

A number of approaches have been suggested to reduce the problem of livestock worm infestation under organic farming. These include management, phytotherapy and homeopathy. The most common management strategies in France include; 1) Ewes and lambs are continuously grazed together on permanent pastures until June when lambs are placed on safe pastures. This approach has produced good economic results. 2) Ewes and lambs are grazed together from turnout until July when the lambs are separated and put on safe pasture. The performance of lambs under this strategy has been poor. 3) Ewes are grazed together with the lambs on permanent pastures until the end of July to mid August when the lambs are separated and grazed on safe pastures. This strategy has produced very poor lambs. Experiments have shown that strongyle infections in set stocked lambs under temperate conditions may lead to no growth during the grazing season (Cabaret, 2002).

Barger (1997) categorized grazing management strategies to control internal parasites as evasive, preventive or diluting. An evasive strategy is one where infected animals are moved to a clean pasture thus avoiding disease-producing pasture. Preventive strategy involves grazing uninfected animals on clean pasture while diluting strategy involves the mixing of susceptible animals with resistance ones. A diluting strategy can also be achieved by reducing the stocking rate or by reducing the duration of grazing on a particular area. Mixed grazing is another grazing 
management used. By rotationally grazing sheep and cattle that are over 12 months of age, worm infestations can be reduced because cattle can pick up worm larvae and are not affected.

Control of worms by grazing management alone has not been successful as reported from many experiments conducted all over the world (Allen, et al, 1998). In most cases, producers have had to use conventional synthetic dewormers, which are organically accepted only for ewes, and not when they are in the third trimester of gestation (Allen, 1998). The highest worm load is observed during the period of parturition and lactation putting the lambs at high risk of worm infestation. According to Allen, stress from worm infestation is pronounced immediately after weaning. Outhouse (2004) suggested that ewes and lambs should be separated daily to reduce worm infestation. However, this would be difficult in practice. In addition, lambs should be creep fed on clean pastures. In Denmark, weaning of lambs in early July before the midsummer rise in worm infections and moving them to clean pastures has produced good results (Cabaret, 2002). Other proposals made to reduce worm problems in organic lamb production include the use of resistant animals. A few breeds of sheep are resistant to internal parasites. These breeds include St. Croix, Gulf Coast Native and Katahdin. However, these animals are low producing. Researchers in Australia and New Zealand have been trying to select resistant animals from productive breeds but the process is slow and there is no commercially available parasite resistant stock (Tritschler, 2003). 


\section{CHAPTER 3: MATERIALS AND METHODS}

\section{Experimental Site Description}

The experiment was conducted at the West Virginia University Horticulture Farm. This Farm is situated in Morgantown, $39^{\circ} 39^{\prime} \mathrm{N}, 79^{\circ} 55^{\prime} \mathrm{W}$ and about $370 \mathrm{~m}$ above sea level (Kandapola, 2002). The farm is 27.2 ha in size and was managed conventionally for over 80 years. The farm underwent transition to organic management in 1999 and was certified as organic in 2003 . The topography is rolling with slopes between 0 and $20 \%$. The soils in the experimental area are: Fenwick series (fine loamy, mixed, mesic Aquick Haplodults); Dormont series (fine-loamy, mixed superactive, mesic Oxyaquick Hapludalfs); Guernsey series (fine, mixed, superactive, mesic Aquic Hapludalfs); Lily series (fine-loamy, siliceous, semiactive, mesic, Typic Hapludults) and Tilsit series (fine-silty, mixed semi active, mesic Typic Fraquidults). The area receives about $762 \mathrm{~mm}$ of precipitation per year. The average maximum summer temperature is $29^{\circ} \mathrm{C}$ (Ruffner, 1980). Buildings, roads, woodland and fence rows occupy about 5.2 ha of the farm, about 17.6 ha are under grassland, dominated by tall fescue, orchard grass and red clover, and 2 ha are under fruit trees, mainly apples, pears, grapes and blueberries. About 2 ha are dedicated to field crops/livestock systems research while 0.4 ha is under market garden systems research.

\section{Experimental Procedure}

In 2000, about 2 ha of the grassland area was divided into three blocks based on the soil type and the previous use (Figure 1). Block II had been an orchard. The apple trees were bulldozed out in January 2000 and the area was seeded on April 28, 2002 with pennlate orchard grass and red clover cv Cinnamon at the rates of $17 \mathrm{~kg} \bullet \mathrm{ha}^{-1}$ and $8 \mathrm{~kg} \bullet \mathrm{ha}^{-1}$, respectively. The area 
was disked and seeded with a Brillion seeder. Twenty three yearling steers and heifers were grazed on block I and III in March and red clover was over-seeded on March 20, 2000 at the rates of $8 \mathrm{~kg} \bullet \mathrm{ha}^{-1}$. Each block was divided into two plots and each plot randomly assigned a high input (compost applied) and a low input (no compost) treatment. On April 11/12 2000, compost was applied to plots $110,112,113,114,116$ and 117 at the rate of $26,950 \mathrm{~kg}^{\bullet} \mathrm{ha}^{-1}$ while to plots 100, 103 and 105 compost was applied at the rate of 28,954 $\mathrm{kg}^{\bullet} \mathrm{ha}^{-1}$ on April 27, 2000 (Figure 1). The compost spread on April 11 and 12, 2000 provided $118 \mathrm{~kg} \mathrm{~N}, 29 \mathrm{~kg} P$ and $78 \mathrm{~kg} \mathrm{~K}$ while that applied on April 27, 2000 provided $124 \mathrm{~kg} \mathrm{~N}, 34 \mathrm{~kg}$ P and $112 \mathrm{~kg} \mathrm{~K}$. No compost was applied in 2001 and 2002. In 2003, compost was applied to plots 100, 103 and 105 on April 3 at the rate of 13,363 $\mathrm{kg} \bullet \mathrm{ha}^{-1}$. This compost provided $60 \mathrm{~kg} \mathrm{~N} \bullet \mathrm{ha}^{-1}, 29 \mathrm{~kg} \mathrm{P} \bullet \mathrm{ha}^{-1}$ and $57 \mathrm{~kg} \mathrm{~K} \bullet \mathrm{ha}^{-1}$. Plots $110,112,113,114,116$ and 117 received compost at the rate of $8,909 \mathrm{~kg}^{\bullet} \mathrm{ha}^{-1}$ on April 3, 2003. The compost provided $49 \mathrm{~kg} \mathrm{~N}, 25 \mathrm{~kg}$ P and $53 \mathrm{~kg} \mathrm{~K}$. On October 24 2003, plots 103, 110 and 112 received compost at the rate of $14,255 \mathrm{~kg} \mathrm{ha}^{-1}$ and this compost provided $72 \mathrm{~kg} \mathrm{~N} \bullet \mathrm{ha}^{-1}$, $35 \mathrm{~kg} \mathrm{P} \cdot \mathrm{ha}^{-1}$ and $73 \mathrm{~kg} \mathrm{~K} \cdot \mathrm{ha}^{-1}$. No compost was applied in 2004. Compost was dairy cattle manure based that was stored in windrows for 6 months to 1 year at the WVU Animal Science Dairy facility and spread using a manure spreader. The low plots had no compost application. In March 2000, lime was applied to plots 111 to 117 at a rate of $6,398 \mathrm{~kg}^{\bullet} \mathrm{ha}^{-1}$ and to plots 100 to 110 at a rate of 2,912 $\mathrm{kg}^{\bullet} \mathrm{ha}^{-1}$. More lime was applied in April 2002 to plots 100 to105 at a rate of 4,455 kg $\mathrm{ha}^{-1}$. All plots were over-seeded with red clover in April 2003 and March 2004 at the rate of $7 \mathrm{~kg} \cdot \mathrm{ha}^{-1}$. The low plots had no compost application. In March 2000, lime was applied to plots 111 to 117 at a rate of $6,398 \mathrm{~kg}^{\bullet} \mathrm{ha}^{-1}$ and to plots 100 to 110 at a rate of 2,912 $\mathrm{kg} \bullet \mathrm{ha}^{-1}$. More lime was applied in April 2002 to plots 100 to105 at a rate of 4,455 $\mathrm{kg} \bullet \mathrm{ha}^{-1}$. All plots were over-seeded with red clover in April 2003 and March 2004 at the rate of $7 \mathrm{~kg} \bullet \mathrm{ha}^{-1}$. 


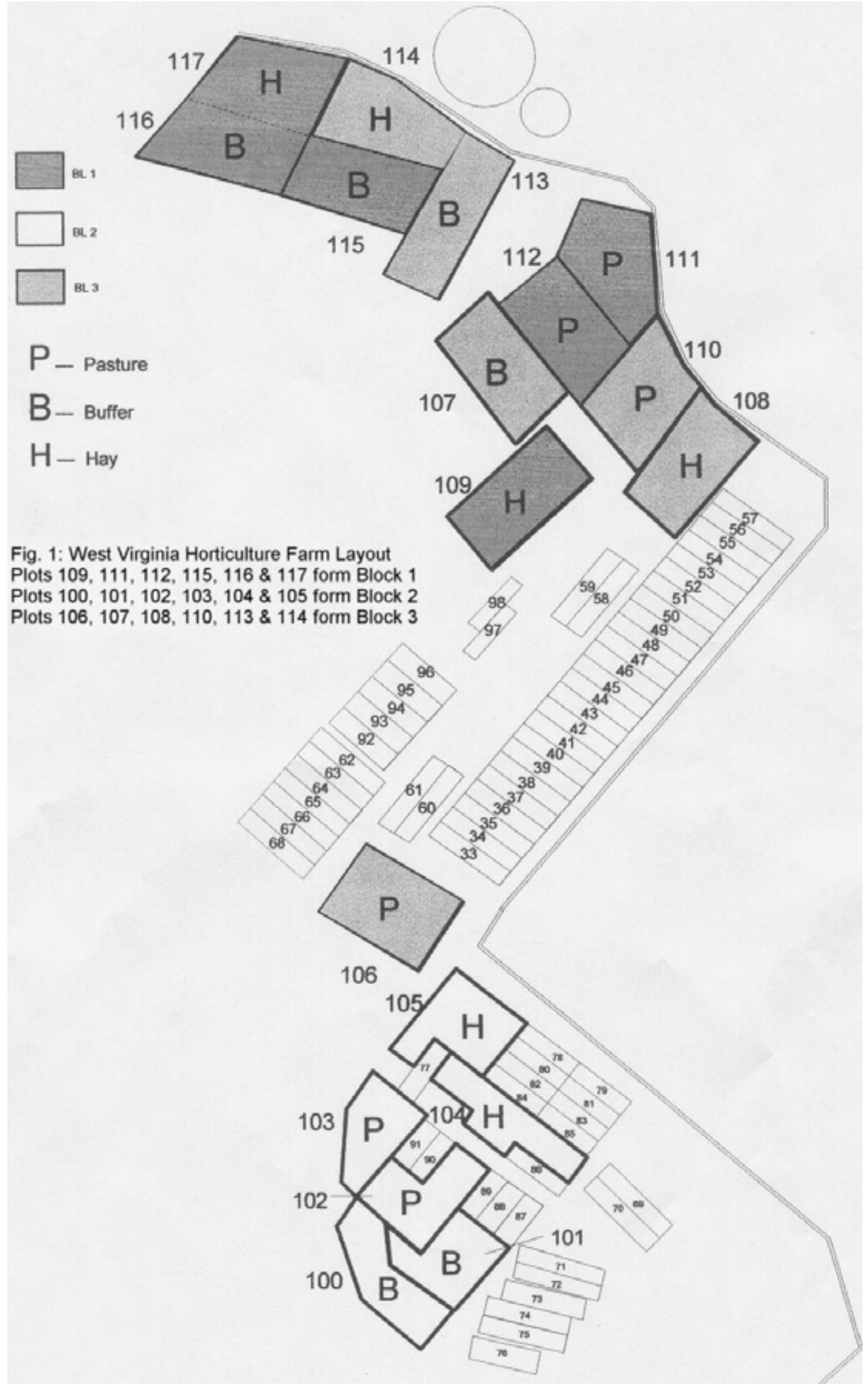


Each plot was subdivided into three subplots of equal sizes and randomly assigned a usage; pasture, hay and buffer. Pasture subplots were grazed. Hay subplots were used for first cutting and aftermath hay and grazed when growth rate of pastures and buffers was low (JulyAugust). Buffer subplots were used as pasture or cut for hay depending on need. For grazing, the subplots were sub divided into paddocks. The number of paddocks depended on usage, time of year and the need to control parasites. A moveable electric netting about $1 \mathrm{~m}$ high was used for paddock separation.

Thirty Horned Dorset x Merino cross ewes were purchased in March 2001. Initially, the ewes rotationally grazed on the experimental plots as one group but were divided into 2 groups in August 2001; one group was put on low input plots and the other on high input plots. A Suffolk ram was acquired in November, 2001 and put with all the ewes in one group for breeding. Lambs were born in April 2002. Six groups of 3 to 4 ewes and their lambs grazed experimental plots, one group to each plot and block. However, the animals were placed in 2 groups again in August 2002 and grazed all high or all low plots from then on. The ewes were bred in one group, off the experimental plots. In 2003, the flock was divided in two groups and assigned to high and low treatments in mid January. Each group occupied the same useage of each block at the same time. All sub plots of each useage were grazed successively in each cycle. Animals were then moved to another useage. Sheep were grazed on buffer and hay plots in winter. They were allowed to graze a paddock for 5 to 6 days because the risk of parasite infection is low in winter. Stocking density was increased during the period mid January to mid April to compensate for the November to mid January period when animals were out of the experimental area for breeding. Stocking density was adjusted so that the return of nutrients from hay fed as a supplement in winter would have equalled what would have been returned if animals 
grazed all winter at the assigned stocking rate.

In 2003, per ha stocking rate was 9.7 ewes and 15.6 lambs for the high treatment and 8.6 ewes and 11.8 lambs for the low treatment while in 2004, the stocking rates were 10.8 ewes and 16.7 lambs for high treatment and 8.6 ewes and 12.2 lambs for low input treatment. In mid April, ewes were allocated to high input treatment and low input treatment based on the pre determined stocking rate of 10 ewes for the high group and 8 ewes for the low input treatment. Using the ratio of 10 ewes to 8 ewes, the ewes were sorted out using their most recent weights such that $55 \%$ of the total weight of all the ewes should come from the 10 ewes in the high input treatment and approximately $45 \%$ to come from the low input treatment group. The number of lambs per ewe was also considered to approximately balance the number of twin lambs and single lambs in the two groups. In 2003, the high input treatment had 5 ewes with twin lambs and 5 ewes with single lambs while the low input treatment had 5 ewes with twin lambs and 3 ewes with single lambs. In 2004, the high input treatment had 6 ewes with twin lambs and 4 ewes had single lambs while the low input treatment had 4 ewes with twin lambs and 4 ewes with single lambs. Ewes grazed rotationally on the pasture together with their lambs as the growing season began. The grazing cycles and schedules for 2003 and 2004 are shown in Table 1. In 2003, first cut hay was harvested from buffer and hay plots on June 24 while the aftermath hay was harvested from hay plots only on September 5. In 2004, first cut hay was harvested from hay and buffer plots on June 24. Aftermath hay was harvested on September 4 from hay plots only. The rotation was designed to allow a minimum of 36 days rest and a grazing time of 3 days or less. 
Table 1. Sheep grazing schedule for 2003; grazing cycles, useage, number of days and number of divisions (paddock)

\begin{tabular}{llllcc}
\hline Cycle & Start & End & Useage & No. days & No. paddocks \\
\hline 1 & Jan. 10 & Feb. 21 & Hay & 42 & 11 \\
1 & March 5 & April 16 & Buffer & 42 & 13 \\
1 & April 16 & June 11 & Pasture & 57 & 21 \\
2 & June 11 & July 8 & Pasture & 28 & 9 \\
2 & July 11 & August 3 & Buffer & 23 & 8 \\
3 & Aug.14 & Sep. 10 & Pasture & 27 & 9 \\
3 & Sep. 10 & Oct. 4 & Buffer & 24 & 8 \\
2 & Oct. 4 & Oct. 18 & Hay & 14 & 6 \\
\hline
\end{tabular}

Sheep were kept in the barn from February 21 to March 5 because of snow. They were removed from July 8 to 11 and from August 3 to 14 to graze on crop rotation experimental plots and from October 18 to mid January 2004 for breeding.

Table 2. Sheep grazing schedule for 2004: grazing cycles, useage, number of days and number of divisions (paddocks)

\begin{tabular}{llllcc}
\hline Cycle & Start & End & Useage & No. days & No. paddocks \\
\hline 1 & Jan. 13 & Feb. 12 & Buffer & 30 & 6 \\
1 & Feb. 12 & March 16 & Hay & 34 & 6 \\
2 & March 16 & April 16 & Buffer & 32 & 4 \\
1 & April 16 & May 25 & Pasture & 36 & 14 \\
3 & May 28 & July 4 & Pasture & 36 & 14 \\
3 & July 4 & July 20 & Buffer & 16 & 8 \\
2 & July 20 & Aug. 7 & Hay & 12 & 6 \\
4 & Aug. 7 & Sep. 13 & Pasture & 36 & 14 \\
4 & Sep. 13 & Oct. 21 & Buffer & 36 & 14 \\
3 & Oct. 24 & Nov. 3 & Hay & 8 & 3 \\
5 & Nov. 3 & Nov. 12 & Pasture & 9 & 3 \\
\hline
\end{tabular}

Sheep were removed from May 9 to May 11, May 25 to May 28 and October 21 to October 24 to graze on the crop rotation plots and from November 12 to January 2005 for breeding.

Herbage mass was measured immediately before and after grazing using either a $0.2 \mathrm{~m}^{2}$ plate meter (Rayburn and Rayburn, 1998) or clipping. Clipping was used for pre-grazing measurements when herbage was higher than $30 \mathrm{~cm}$. Three forage samples were clipped from each paddock. The three samples were taken across the middle of the paddock, keeping $1 \mathrm{~m}$ from the fences. A manual hedge clipper was used to clip the forage from a 14 by $40.5 \mathrm{~cm}$ quadrat at 
ground level. The clipped vegetation was hand sorted in the laboratory into, grasses, legumes, weeds and dead material. In 2004, only one sub-sample from each paddock was sorted for botanical composition. The sorted samples were oven dried for 48 hours at $80^{\circ} \mathrm{C}$ and weighed. Samples not sorted the same day of clipping were kept in the refrigerator for short periods or in the freezer for longer periods. At least ten plate meter measurements were taken per paddock at regular intervals along a walk line through the middle of the paddock, keeping $1 \mathrm{~m}$ from the fences. These measurements were averaged to give the sward height of the paddock. The same method was used to measure residual height of each paddock immediately after moving the sheep to the next paddock. Sward height was converted to herbage mass using the following equation:

Herbage mass $=231.48 \mathrm{X}$ sward height -81.91. Herbage removed at each grazing was calculated as follows:

Herbage removed $(\mathrm{hm})=$ herbage mass before grazing $(\mathrm{tdm})-$ residual herbage mass $(\mathrm{rhm})$, with the assumption that herbage growth during this period is negligible.

Forage samples were taken from the hay and buffer plots just before mowing. A sickle bar mower with a blade width of $77.5 \mathrm{~cm}$ was used to clip the forage at $5 \mathrm{~cm}$. Herbage from three strips each about $5 \mathrm{~m}$ long was clipped, gathered and weighed. A fraction of the harvested material (about $0.5 \mathrm{~kg}$ ) was taken and hand sorted into, grasses, legumes, weeds and dead material. Sorted materials were oven dried for 48 hours at $80^{\circ} \mathrm{C}$ and weighed.

Before the start of the experiment (Feb. 2000), soil samples, 0 to $5 \mathrm{~cm}$ deep, were taken from the experimental plots using a soil corer along 3 walk lines. From 15 to 25 cores were taken from each subplot following the same pattern each fall. Samples were air dried and sent to the WVU soil testing lab for routine analysis. 


\section{Management of Sheep (2003 and 2004)}

There were 15 lambs in the high treatment plots in 2003. However, one lamb was only on the experimental area for half the time and was assumed to be half a lamb in the calculations, therefore bringing the number of lambs considered in the analysis to 14.5. Twelve lambs were initially in the low treatment plots in 2004. However, one was on the experimental plots a quarter of the time and was considered as a quarter of a lamb. This reduced the number of lambs in the low treatment area to 11.3. In 2004, following similar methodologies as above the high input treatment had 15.5 lambs. The average number of days from birth to weaning was 106 and 113 for 2003 and 2004, respectively. Lambing took place from late March to mid April. Lambs were weighed at birth; navel clipped at 2 to $3 \mathrm{~cm}$ and dipped in $7 \%$ tincture of iodine solution. Soon after lambing, the teats of the ewes were stripped to remove the wax plug and allow the milk to pass through. Docking and castration were done between 2 days and 2 weeks of age. Lambs were weighed at weaning (about 4 months of age) and about one month after weaning. In 2003, weaning took place on August 21 when the lambs were on pasture plots while in 2004 it took place on August 6 when lambs grazed on hay plots.

Ewes were weighed on August 21 and October 30 in 2003 and on June 21 and October 26 in 2004 while lamb weights were taken on June 11, August 21 and November 7 in 2003 and on June 21, August 6, September 7, October 7 and October 26 in 2004. Hay was fed in the paddocks as needed. Some grain, mainly wheat from the farm and corn/soybean purchased from Twin Parks Organic Farm was used as a supplement before and after lambing and before breeding when ewe body condition score fell below an average of 2.5 , based on a scale of 1 to 5 . Grain supplement started at $113 \mathrm{~g}$ per ewe and was increased by the same amount after each 
week to a maximum of $700 \mathrm{~g}$ per sheep. Mineralized salt was provided ad libidum. It contained 24\% Ca, 6\% P, 21\% NaCl, 1\% Mg, 1\% S, 30 ppm I, 6 ppm Co, 32 ppm Se, 1800 ppm Zn, 1500 ppm Mn, $500 \mathrm{IU} / \mathrm{lb}$ vitamin A, 25,000 IU/lb vitamin D and $200 \mathrm{IU} / \mathrm{lb}$ vitamin E. Other management practices included hoof trimming in spring, summer and fall. Enterotoxaemia vaccination was administered in spring prior to lambing. The lambs also got enterotoxemia vaccine at 5 to 7 weeks of age. Enzootic abortion of ewes' vaccine (EAE) was administered 45 to 60 days before breeding. A combined vaccine against Clostridium perfringens (type $\mathrm{C}$ and D) and tetanus was given to ewes 30 days before lambing while the lambs were inoculated at 30 and 60 days of age. Sheep were shorn in spring before lambing and fleece weight of individual animals was taken in 2004.

A randomized complete block experimental design with 3 blocks, 2 treatments (main plots) and 3 subplots was used. Analysis of variance was used to compare soil fertility, herbage accumulation and botanical composition between the treatments (SAS, 1990). For lamb and ewe performance, there were no field replicates, animals were used as replicates. 


\section{CHAPTER 4: RESULTS AND DISCUSSION}

\section{Weather}

Temperature and precipitation for 2003 and for January to September of 2004 from the Morgantown airport (4 km east of the farm) are summarized in Tables 3. In 2003, the average mean monthly temperature for January, February and March was $0.1^{\circ} \mathrm{C}$ and this was about $1.0^{\circ} \mathrm{C}$ lower than the average of the normal mean monthly temperatures. The average mean monthly temperature during the growing season (April-September) was $18.3^{\circ} \mathrm{C}$. This was $5.5^{\circ} \mathrm{C}$ higher than the normal $\left(12.8^{\circ} \mathrm{C}\right)$ but was still favorable for plant growth. In 2004 , the average mean monthly temperature between January and March was $1.4^{\circ} \mathrm{C}$. This was about $0.4^{\circ} \mathrm{C}$ higher than the average mean normal temperature. The average mean monthly temperature during the growing season (April-September) of 2004 was $19^{\circ} \mathrm{C}$. This was $0.7^{\circ} \mathrm{C}$ higher than the mean temperature for the same period in 2003 and about $6.2^{\circ} \mathrm{C}$ higher than the normal $\left(12.8^{\circ} \mathrm{C}\right)$ for the same period. In 2003, a total of $1096.5 \mathrm{~mm}$ of precipitation was received between April and October. This was $426.5 \mathrm{~mm}$ above the normal total for that period. The high amount of precipitation and favorable temperatures resulted in good herbage growth during the growing season. However, prolonged rainy periods in May and June delayed first cutting hay harvesting and as a result first cutting hay was harvested past full bloom. In 2004, the period between April and September received a total of $670 \mathrm{~mm}$ of precipitation. This was about $85 \mathrm{~mm}$ more than the normal precipitation for that period. Similarly to 2003, herbage growth was good but rainy conditions delayed first cutting hay harvesting. In both years, humidity and temperatures were relatively higher than normal. 
Table 3. Monthly average daily temperatures and monthly precipitation for 2003/2004 and normal from a 33 year average (1946-1978), Morgantown airport.

\begin{tabular}{|c|c|c|c|c|c|c|}
\hline \multirow[b]{3}{*}{ Month } & \multicolumn{3}{|c|}{ Temperature } & \multicolumn{3}{|c|}{ Precipitation } \\
\hline & \multicolumn{2}{|c|}{ Year } & \multirow[t]{3}{*}{$\overline{\text { Normal }}$} & \multicolumn{2}{|c|}{ Year } & \multirow[t]{2}{*}{ Normal } \\
\hline & 2003 & 2004 & & 2003 & 2004 & \\
\hline & & ${ }^{\circ} \mathrm{C}$ & & & $\mathrm{mm}$ & \\
\hline January & -4.4 & -4.1 & -2.0 & 68.3 & 101.9 & 74.9 \\
\hline February & -1.8 & 1.1 & 0.2 & 100.8 & 61.0 & 64.4 \\
\hline March & 6.4 & 7.3 & 5.1 & 47.0 & 114.3 & 91.7 \\
\hline April & 12.4 & 11.9 & 11.2 & 66.0 & 99.1 & 89.2 \\
\hline May & 15.7 & 19.3 & 16.4 & 226.6 & 114.3 & 93.8 \\
\hline June & 19.1 & 20.3 & 20.9 & 109.5 & 109.2 & 99.3 \\
\hline July & 22.3 & 22.4 & 22.7 & 304.8 & 91.4 & 101.4 \\
\hline August & 22.7 & 20.9 & 22.1 & 165.4 & 144.8 & 116.1 \\
\hline September & 17.6 & 19.3 & 18.7 & 137.2 & 111.8 & 85.3 \\
\hline October & 11.2 & & 12.8 & 87.9 & & 62.0 \\
\hline
\end{tabular}

\section{Soil Fertility}

The effect of year on soil $\mathrm{pH}$, soil available $\mathrm{P}, \mathrm{Ca}, \mathrm{K}$ and $\mathrm{Mg}$ was highly significant (Table 4). There was no effect of year on OM. There was an effect of useage on soil Mg. There was a treatment by year interaction for soil available $\mathrm{P}$ and soil available $\mathrm{Mg}$ but no interaction for soil $\mathrm{pH}$, available $\mathrm{K}, \mathrm{OM}$ and $\mathrm{Ca}$. There was a treatment by useage interaction for soil available $\mathrm{K}$, soil $\mathrm{pH}$ and soil available $\mathrm{P}$. However, there was no treatment by useage interaction for soil $\mathrm{OM}, \mathrm{Ca}$ and $\mathrm{Mg}$ and no useage by year interactions. There was no effect of input on the soil fertility parameters measured.

Soil $\mathrm{pH}$ increased from 5.5 in 2000 to 6.9 in 2004 with the greatest increases occurring between 2000 and 2001 and also between 2002 and 2003 (Table 5). The increase in soil pH between 2000 and 2001 and between 2002 and 2003 was due to liming in 2000 and 2002 (Figure 2). Soil available $P$ increased from $44 \mathrm{~kg} \bullet \mathrm{ha}^{-1}$ in 2000 to $112 \mathrm{~kg} \bullet \mathrm{ha}^{-1}$ in 2004 . The greatest increase of P was between 2000 and 2001 and between 2002 and 2003. Phosphorus increased in 
both input treatments from 2000 to 2004 (Table 6), but the increase was significantly higher in the high input plots than in the low input plots. The higher increase in soil available $\mathrm{P}$ in the high input treatment plots was due to compost application. The amount of $\mathrm{P}$ also increased in the low input treatment plots. This increase was mainly due to lime application and recycling of nutrients by the grazing sheep. Two year (2000 and 2003) application of compost (compost provided an average of $31 \mathrm{~kg} \mathrm{P}$ ) and lime increased soil available P from $35 \mathrm{~kg} \bullet \mathrm{ha}^{-1}$ in 2000 to $128 \mathrm{~kg} \bullet \mathrm{ha}^{-1}$ in 2004 while the increase in the low input plots was from $55 \mathrm{~kg} \cdot \mathrm{ha}^{-1}$ in 2000 to $97 \mathrm{~kg} \mathrm{P} \cdot \mathrm{ha}^{-1}$ in 2004 (Table 6).

Table 4. Significance of $F$ tests for soil $\mathrm{pH}$, available $\mathrm{P}, \mathrm{OM}, \mathrm{Ca}$ and $\mathrm{Mg}$.

\begin{tabular}{lllllll}
\hline Test & $\mathrm{pH}$ & $\mathrm{P}$ & $\mathrm{K}$ & $\mathrm{OM}$ & $\mathrm{Ca}$ & $\mathrm{Mg}$ \\
\hline Year & $* * *$ & $* * *$ & $*$ & $\mathrm{NS}$ & $* * *$ & $*$ \\
Use & $\mathrm{NS}$ & $\mathrm{NS}$ & $\mathrm{NS}$ & $\mathrm{NS}$ & $\mathrm{NS}$ & $* *$ \\
Input & $\mathrm{NS}$ & $\mathrm{NS}$ & $\mathrm{NS}$ & $\mathrm{NS}$ & $\mathrm{NS}$ & $\mathrm{NS}$ \\
Input x Year & $\mathrm{NS}$ & $* *$ & $\mathrm{NS}$ & $\mathrm{NS}$ & $\mathrm{NS}$ & $*$ \\
Input x Use & $*$ & $*$ & $* *$ & $\mathrm{NS}$ & $\mathrm{NS}$ & $\mathrm{NS}$ \\
Use x Year & $\mathrm{NS}$ & $\mathrm{NS}$ & $\mathrm{NS}$ & $\mathrm{NS}$ & $\mathrm{NS}$ & $\mathrm{NS}$ \\
\hline
\end{tabular}

$*, * *, * * *$ F-tests were significant at, $P<0.05, P<0.01, P<0.001$ respectively.

NS: Non significant

Table 5. Soil pH, available P, K, OM, Ca and Mg from 2000-2004.

\begin{tabular}{|c|c|c|c|c|c|c|}
\hline Year & $\mathrm{pH}$ & $\mathrm{P}$ & K & $\mathrm{Ca}$ & $\mathrm{Mg}$ & $\mathrm{OM}$ \\
\hline & & & \multicolumn{2}{|c|}{$\mathrm{kg} \mathrm{ha}^{-1}$} & - & $\%$ \\
\hline 2000 & 5.5 & 44 & 344 & 2145 & 330 & 5.4 \\
\hline 2001 & 6.4 & 92 & 389 & 5656 & 319 & 4.8 \\
\hline 2002 & 6.5 & 85 & 431 & 5546 & 341 & 5.2 \\
\hline 2003 & 6.9 & 118 & 452 & 7836 & 361 & 5.2 \\
\hline 2004 & 6.9 & 112 & 385 & 6703 & 344 & 5.5 \\
\hline
\end{tabular}

Soil samples were taken in February of 2000, fall 2000, fall 2001, fall 2002 and fall 2003.

Potassium increased from $344 \mathrm{~kg} \bullet \mathrm{ha}^{-1}$ in 2000 to $452 \mathrm{~kg} \bullet \mathrm{ha}^{-1}$ in 2003 and then dropped to $385 \mathrm{~kg}^{\bullet} \mathrm{ha}^{-1}$ in 2004 (Table 5, $P<0.001$ ). The highest increase was between 2000 and 2001 
and also between 2002 and 2003. There was no effect of input on soil available K, and no input by year or use by year interaction for this measure. However, there was an input by use interaction on available K. There was a significant effect of year on soil available K. Soil available $\mathrm{K}$ was significantly lower in the high input buffer and hay plots than in the corresponding low input plots but was higher in the high input pasture plots than in low input pasture plots (Table 7).

Calcium increased from 2,145 $\mathrm{kg}^{\bullet} \mathrm{ha}^{-1}$ in 2000 to the highest value of $7,836 \mathrm{~kg}^{\bullet} \mathrm{ha}^{-1}$ in 2003 and dropped to $6,703 \mathrm{~kg}^{\bullet} \mathrm{ha}^{-1}$ in 2004 . These changes were similar to those for soil available $\mathrm{P}$ and available $\mathrm{K}$ and paralleled the increase in $\mathrm{pH}$ due to liming. The increase of $\mathrm{pH}$ through liming released $\mathrm{P}$ that would otherwise get precipitated by aluminum and iron oxides at soil $\mathrm{pH}$ below 6.5 while $\mathrm{K}$ increased because of the increased cation exchange capacity due to increased $\mathrm{pH}$.

Table 6. Soil available P levels in the high and low input treatments from 2000 to 2004.

\begin{tabular}{lccccc}
\hline & \multicolumn{5}{c}{ Year } \\
Input & 2000 & 2001 & 2002 & 2003 & 2004 \\
\cline { 2 - 6 } & \multicolumn{5}{c}{$\mathrm{kg} \mathrm{ha}^{-1}$} \\
\cline { 4 - 6 } No compost & 55 & 87 & 80 & 108 & 97 \\
Compost & 35 & 98 & 90 & 127 & 128 \\
\hline
\end{tabular}


Figure 2. The effect of compost and year on soil available P. Lime $(\mathrm{CaCo} 3)$ was applied in March 2000 to plots 111 to plot 117 at a rate of $6,398 \mathrm{~kg} \mathrm{ha}^{-1}$ and to plots 100 to 105 at a rate of 2,912 kg ha ${ }^{-1}$ and in April 2002 to plots 100 to 105 at the rate of $4,455 \mathrm{~kg}$ ha $^{-1}$

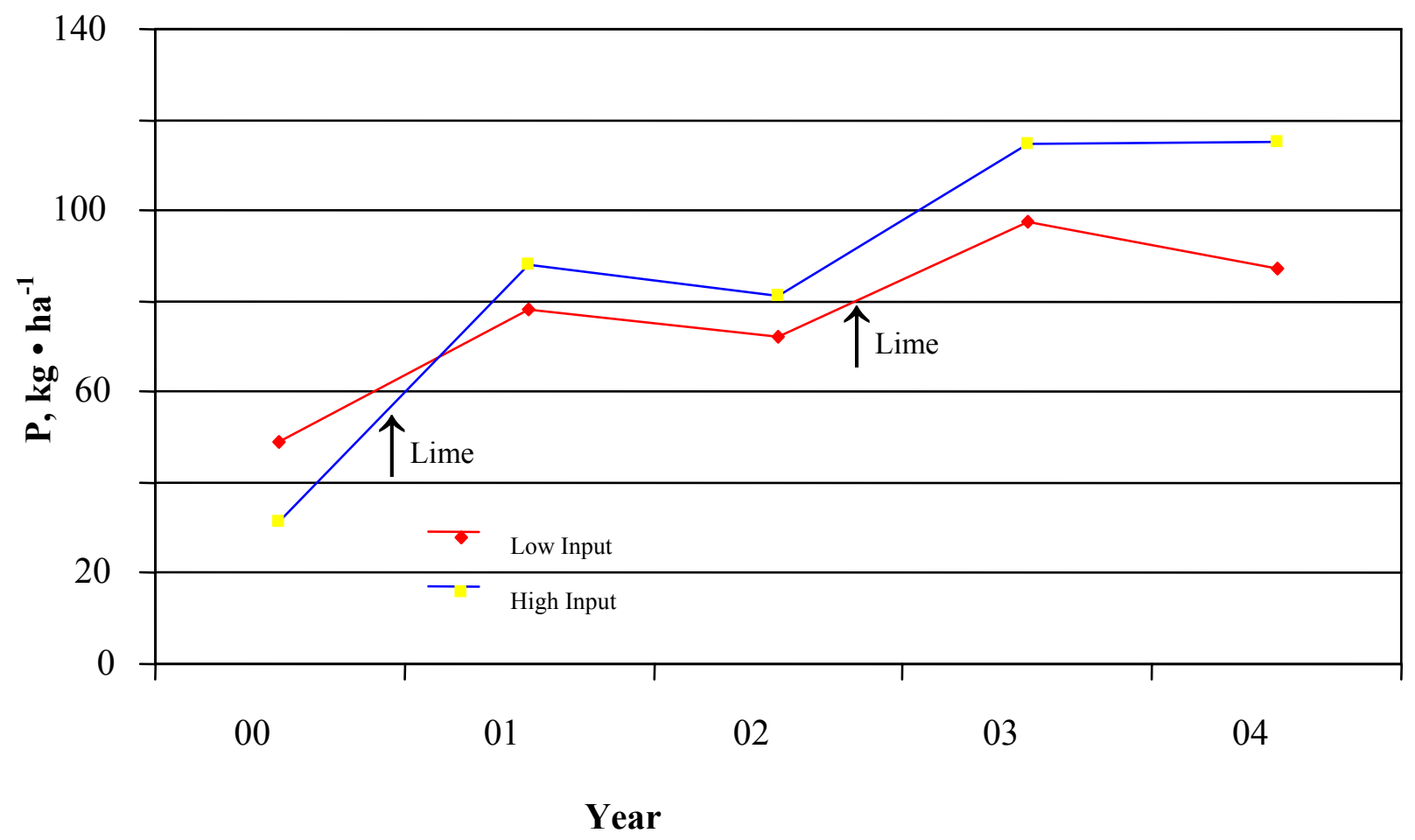

Table 7. The effect of useage and input treatment on soil available $\mathrm{K}$

\begin{tabular}{lccc}
\hline Useage & No compost & & Input \\
& & & Compost \\
\cline { 2 - 2 } & & $\mathrm{kg} \mathrm{ha}^{-1}$ & \\
Pasture & 347 & & 511 \\
Buffer & 414 & & 359 \\
Hay & 392 & & 376 \\
\hline
\end{tabular}

\section{Herbage production from grazed plots}

Herbage consumed from the pasture usage was significantly higher in the high input treatment than in the low input treatment (Table 8). There was a highly significant difference in 
available herbage between the low input and the high input treatment. Residual herbage mass remaining on pasture useages, after grazing, was not significantly different. The mean residual herbage mass for low input and high input treatment plots was $1,055 \mathrm{~kg}^{\bullet} \mathrm{ha}^{-1}$ and $1,011 \mathrm{~kg} \bullet \mathrm{ha}^{-1}$, respectively. This meant that grazing pressure was similar for both treatments. There were no input by year interactions.

No herbage production data for grazing of buffer and hay useages are available for 2003. Grazing was divided into 3 periods in 2004 (Table 9). Hay and buffer useages were grazed from January to mid April, pasture from mid April to early July and buffer and hay from early July to early August when lambs were weaned. Input had no effect on herbage consumed, available herbage or residual when all useages and periods were combined (Table 10). However, the amount consumed from compost treated plots was higher $(P<0.13)$. Lack of a significant difference between inputs was due to the lower herbage mass on buffer and hay useages in periods 1 and 3 when growth was low.

Herbage consumed was not significantly different between useages however, available herbage were different $(P<0.001)$ between useages. More herbage was available in pasture useage $\left(3,705 \mathrm{~kg} \bullet \mathrm{ha}^{-1} \mathrm{~kg}\right)$, followed by buffer useage $\left(1,989 \mathrm{~kg}^{\bullet} \mathrm{ha}^{-1}\right)$ and hay useage $(1,320 \mathrm{~kg} \bullet$ $\mathrm{ha}^{-1}$ ). More herbage was available in pasture useage because it was grazed in spring and early summer when herbage growth was high. Hay useage had the least available herbage because it was grazed in winter and after first cutting hay had been harvested. Residual herbage mass was not significantly different between useages (Table 11).

Herbage consumed was significantly higher in period $2(P<0.001)$ than in period 1 and 3 , while period 1 and 3 were not different. Available herbage was greater in period $2(P<0.001)$ than in period 1 and 3, while period 1 and 3 were $(P<0.05)$ different. Residual herbage mass was 
significantly different $(P<0.001)$ between periods $($ Table 9$)$. More herbage was available in period 2 because the late spring and summer season caused higher herbage growth. Residual herbage was more in period 2 because of the high herbage growth rate, while there was less residual herbage mass in period 3 because herbage growth rate was low and sheep grazed on the aftermath.

Table 8. Herbage consumed, available herbage and residual herbage mass from pasture useage 2004). of low (no compost) treatment and high input (compost) plots (averages of 2003 and

\begin{tabular}{lccc}
\hline Input & Herbage consumed $^{1}$ & Available herbage $^{2}$ & Residual $^{2}$ \\
\cline { 2 - 2 } \cline { 4 - 4 } & & $\mathrm{kg} \mathrm{ha}^{-1}$ & \\
No compost & 7,905 & 3,687 & \\
Significance & $* *$ & $*$ & 1,055 \\
Compost & 10,357 & 4,469 & $\mathrm{NS}$ \\
\hline
\end{tabular}

${ }^{1}$ Total per year

${ }^{2}$ Average per cycle

$3 *$, **, F-tests were significant at $\mathrm{P}<0.05, \mathrm{P}<0.01$, respectively.

NS: Non significant

Table 9. Herbage consumed, available herbage and residual herbage mass for each period in 2004.

\begin{tabular}{|c|c|c|c|c|c|c|}
\hline Period & Usage & Cycle & Date & $\begin{array}{l}\text { Herbage } \\
\text { consumed }\end{array}$ & $\begin{array}{l}\text { Available } \\
\text { herbage }\end{array}$ & Residual \\
\hline & & & & 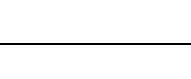 & ha ${ }^{-1}$ cycle & \\
\hline \multirow{3}{*}{1} & Buffer & 1 & Jan. 13-Feb 12 & & & \\
\hline & Hay & 1 & Feb. 12-March 16 & 568 & 1058 & 337 \\
\hline & Buffer & 2 & March 16-April 16 & & & \\
\hline & Pasture & 1 & April 16-May 9 & & & \\
\hline \multirow[t]{2}{*}{2} & Pasture & 2 & May 11-May 25 & 2678 & 3705 & 1134 \\
\hline & Pasture & 3 & May 28-July 4 & & & \\
\hline \multirow[t]{2}{*}{3} & Buffer & 3 & July 4-July 20 & 740 & 1688 & 228 \\
\hline & Hay & 2 & July 20-Aug. 7 & & & \\
\hline
\end{tabular}


Table 10. Effect of input treatment on herbage consumed, available herbage and residual herbage mass from pasture, buffer and hay useages, 2004.

\begin{tabular}{|c|c|c|c|}
\hline Input & Herbage consumed & Available herbage & Residual \\
\hline & & \multicolumn{2}{|l|}{$\mathrm{kg} \mathrm{ha}^{-1} \mathrm{cycle}^{-1}$} \\
\hline No compost & 1271 & 2107 & 836 \\
\hline Compost & 1606 & 2408 & 802 \\
\hline
\end{tabular}

Not significantly different.

Table 11. Effect of useage on herbage consumed, available herbage and residual herbage mass, 2004.

\begin{tabular}{|c|c|c|c|}
\hline Useage & $\begin{array}{c}\text { Herbage } \\
\text { consumed }\end{array}$ & Available herbage & Residual \\
\hline & & $\mathrm{kg} \mathrm{ha}^{-1}$ cycle $^{-1}$ & \\
\hline Pasture & 2676 & 3705 & 1029 \\
\hline Buffer & 1151 & 1989 & 839 \\
\hline Hay & 639 & 1320 & 682 \\
\hline
\end{tabular}

Effect on herbage consumed and residual was not significant. Effect on available herbage was significant $(P<0.001)$

\section{First Cut Hay Production and Botanical Composition}

High input plots produced significantly $(P<0.05)$ higher amounts of hay than low input plots (Table 12). Buffer useage produced more first cutting hay than hay useage (Table 13). This was probably due to the effect of grazing. Buffer useage was grazed more times than hay useage and that may have led to more recycling of nutrients

The proportion of weeds was $(P<0.05)$ higher in the low input treatment plots than in the high input treatment plots. A probable explanation is that grass growth was higher in the high input treatment plots and this offered stronger competition to the weeds. Lower grass growth in low input treatment plots caused the weeds to be relatively higher than in high input treatment 
plots. The amount of grass, legume and dead material were not significantly different between inputs and useages. Legume proportion was higher in both input treatments in 2003 than in 2004 (Table 14).

Table 12. Effect of input treatment on first cutting hay production.

\begin{tabular}{|c|c|c|c|c|c|}
\hline Input & Herbage available & Grass & Legume & Weed & Dead \\
\hline & $\mathrm{kg} \mathrm{ha}^{-1}$ & & \multicolumn{2}{|c|}{$\%$} & \\
\hline No compost & 4,912 & 79 & 11 & 7 & 4 \\
\hline Significance & $*$ & NS & NS & $*$ & NS \\
\hline Compost & 5,713 & 78 & 17 & 2 & 4 \\
\hline
\end{tabular}

Table 13. Effect of useage on first cutting hay production.

\begin{tabular}{|c|c|c|c|c|c|}
\hline Useage & $\begin{array}{l}\text { Available } \\
\text { herbage }\end{array}$ & Grass & Legume & Weed & Dead \\
\hline & $\mathrm{kg} \mathrm{ha}^{-1}$ & & \multicolumn{2}{|c|}{$\%$} & \\
\hline Buffer & 6,055 & 80 & 12 & 3 & 5 \\
\hline Significance & $* * *$ & NS & NS & NS & NS \\
\hline Hay & 4,570 & 77 & 15 & 5 & 3 \\
\hline
\end{tabular}

Table 14. First cutting hay production and botanical composition from buffer and hay useages for 2003 and 2004

\begin{tabular}{|c|c|c|c|c|c|}
\hline Year & $\begin{array}{l}\text { Available } \\
\text { herbage }\end{array}$ & Grass & Legume & Weed & Dead \\
\hline & $\mathrm{kg} \mathrm{ha}^{-1}$ & & \multicolumn{2}{|c|}{$\%$} & \\
\hline 2003 & 4675 & 75 & 19 & 3 & 3 \\
\hline Significance & NS & NS & $\dagger$ & NS & NS \\
\hline 2004 & 4683 & 82 & 9 & 5 & 4 \\
\hline
\end{tabular}

$\dagger$ Difference significant at $P<0.09$.

\section{Lamb Production}

There was no difference in individual lamb performance (daily weight gain per lamb) between the high and the low treatment groups. However, there was a difference in lamb 
production per ha (Table 15). The difference in lamb production $\bullet \mathrm{ha}^{{ }^{-1}} \mathrm{year}^{-1}$ between high input treatment plots and low input treatment plots was $74 \mathrm{~kg}^{\bullet} \mathrm{ha}^{-1}$. This was due to the higher stocking rates in the high input treatment plots (15.6 and 16.7 lambs ha $^{-1}$ in 2003 and 2004, respectively) than the low input treatment plots (11.8 and 12.2 lambs for 2003 and 2004, respectively). Because there was no significant difference in residual herbage mass between high and low treatment plots, higher production of lamb $\mathrm{ha}^{-1}$ was due to higher herbage production in the high input plots.

More lamb was produced in 2003 than in 2004. In 2003, $436 \mathrm{~kg} \cdot \mathrm{ha}^{-1}$ of lamb was produced in the high treatment plots while the low input treatment plots produced $381 \mathrm{~kg} \cdot \mathrm{ha}^{-1}$ in the same year. In 2004, lamb production was $369 \mathrm{~kg} \bullet \mathrm{ha}^{-1}$ and $277 \mathrm{~kg}^{\bullet} \mathrm{ha}^{-1}$ for high and low input treatments respectively (Table 15). In both 2003 and 2004, lamb growth was highest from birth to mid June (Figure 3 and 4). Lower growth rate from mid June to weaning was probably due to lower milk production of the ewes and as a result, lambs competed with them for herbage. However, lambs would have been at a disadvantage because their physiological growth stage required a high plane of nutrition to maintain good growth rates. The slowing of growth rate may also have been due to parasite infections. After mid June, lambs gained weight at a slower rate in 2004 than 2003. This was probably due to a higher incidence of internal parasites in 2004 than 2003. Although the incidence of parasites was not adequately covered in the study, observations that included symptoms of sick lambs and occasionally worm segments in the field indicated higher levels of worm infestations in 2004 than 2003. This could explain the lower lamb production ha $^{-1}$ and the lower lamb growth rate day $^{-1}$ in 2004 than in 2003. Because of higher worm infestation in 2004 than 2003, 10 lambs and 3 ewes were dosed with ivomectin in 2004. Seven of the lambs and 2 ewes dosed were from the high input treatment. The high stocking rate 
probably worsened the worm problem. No experimental animal was dosed in 2003.

Table 15. Effect of input treatment on lamb production ha $^{-1}$ and weight gain $\bullet$ day $^{-1}$ for 2003 and 2004.

\begin{tabular}{llll}
\hline Input & Year & Lamb production & Lamb weight gain \\
\hline & & $\mathrm{kg} \mathrm{ha}^{-1}$ & $\mathrm{~g} \mathrm{head}^{-1} \mathrm{day}^{-1}$ \\
No compost & 2003 & 381 & 241 \\
No compost & 2004 & 277 & 171 \\
Compost & 2003 & 436 & 208 \\
Compost & 2004 & 369 & 165 \\
\hline
\end{tabular}

Lamb production per ha was $(P<0.001)$ lower in the low input treatment than in the high input treatment. Lamb production and performance was $(P<0.001)$ lower in 2004 than in 2003

Figure 3. Lamb growth curves, 2003. Values in kg.

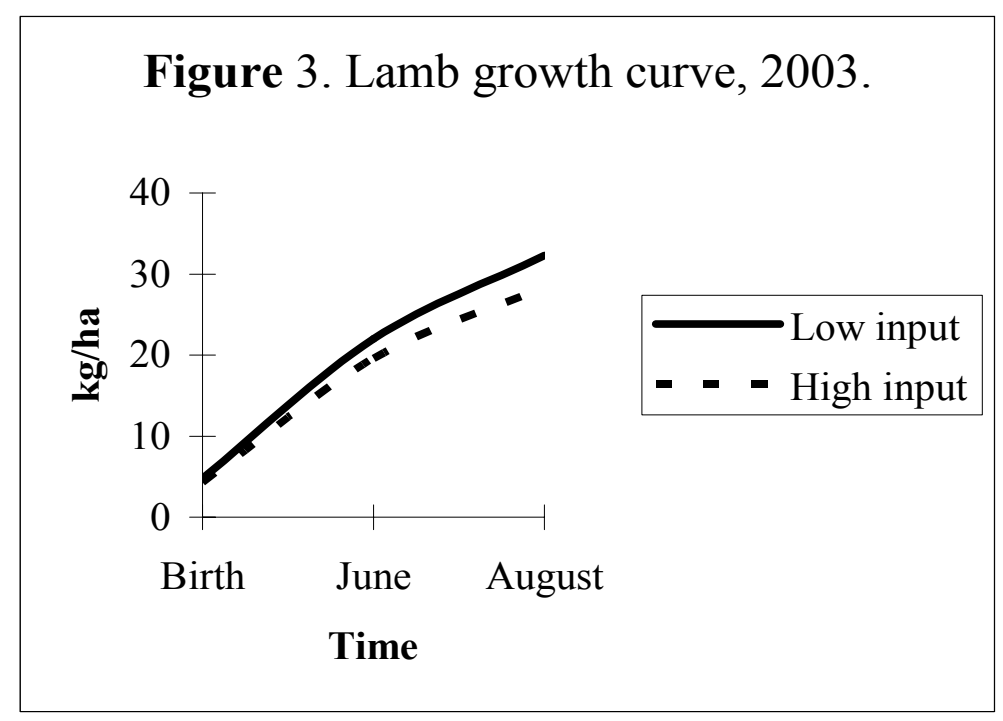


Figure 4. Lamb growth curves, 2004. Values in $\mathrm{kg}$.

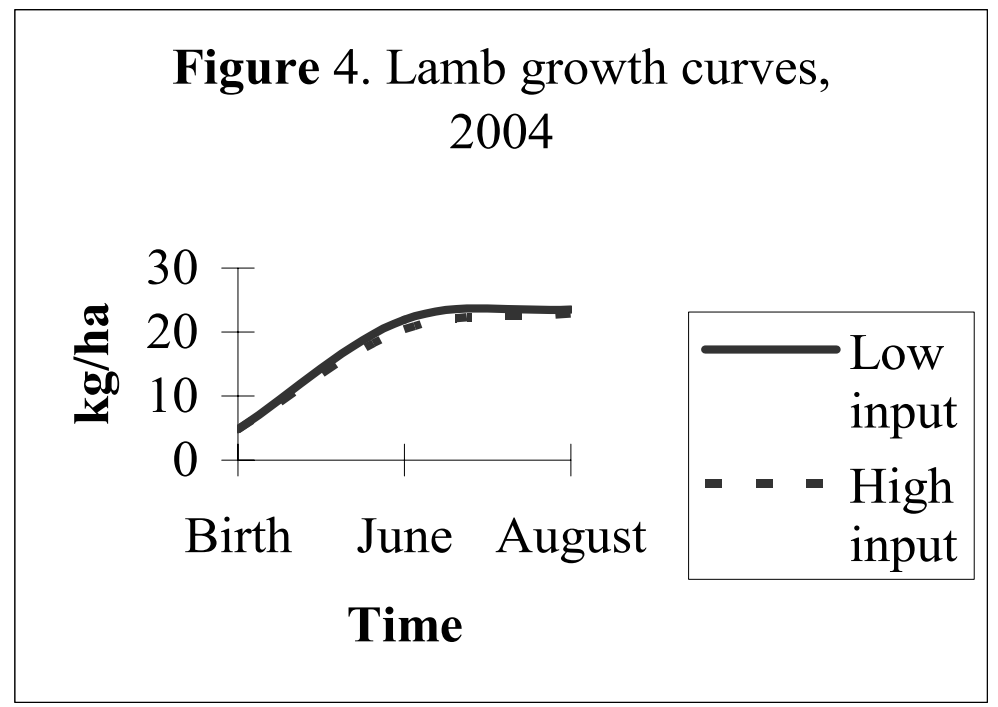

\section{Ewe Performance}

There was no significant difference in the mean ewe weights between high and low treatment but there was a significant difference in the mean weights between years, being lower in $2003(24.9 \mathrm{~kg})$ than $2004(55.8 \mathrm{~kg})$. The difference, however, cannot be attributed only to years because the ewes subjected to the experiment in 2003 were not all the same ones used in 2004. Wool data were taken in 2004 and not in 2003. There was no significant difference in wool production between the low input treatment and the high input treatment. Each ewe produced an average of $2.7 \mathrm{~kg}$ wool. 


\section{CHAPTER 5: CONCLUSION}

The use of compost for a period of 4 years on an organic grassland system increased $\mathrm{P}$ and $\mathrm{Mg}$ in the soil but did not change the status of organic matter and did not change soil $\mathrm{pH}$. Liming increased soil $\mathrm{pH}$. The increase in soil $\mathrm{pH}$ due to liming increased soil available $\mathrm{P}$ and $\mathrm{K}$.

More herbage was consumed in the high input treatment plots than the low input treatment plots. The mean herbage consumed per year from pasture useage for the two years was $7,905 \mathrm{~kg} \cdot \mathrm{ha}^{-1}$ for the low input treatment plots and $10,359 \mathrm{~kg} \cdot \mathrm{ha}^{-1}$ for high input treatment. More herbage $\left(4,469 \mathrm{~kg} \cdot \mathrm{ha}^{0^{-1}} \mathrm{cycle}^{-1}\right)$ was available in the high input treatment than in the low input treatment $\left(3,687 \mathrm{~kg} \bullet \mathrm{ha}^{-1} \mathrm{cycle}^{-1}\right)$. Residual herbage mass for all usages were not different between the treatments. This meant that the average stocking rate used (10.3 ewes and 15.9 lambs for high input treatment and 8.6 ewes and 11.6 lambs for low input treatment) was supported by available herbage resources. Period 2 had more residual herbage mass than period 3 and 1. This was because of the high growth rate of herbage in the period, thus leading to a surplus of herbage.

An average of $403 \mathrm{~kg} \mathrm{lamb} \cdot \mathrm{ha}^{-1}{ }^{-1} \mathrm{year}^{-1}$ was produced in the high treatment plots while the low input plots produced an average of $329 \mathrm{~kg}$ lamb ha $^{0^{-1}} \mathrm{year}^{-1}$. Although not different from one another, the average lamb weight gain in the high treatment plots was $187 \mathrm{~g} \bullet$ day $^{-1}$ while the average weight gain of lambs grazing on the low input plots was $206 \mathrm{~g} \cdot$ day $^{-1}$. However, the average production per ha was significantly lower in the low input plots compared to the high input plots. The difference in lamb production per unit area was a result of higher herbage production, allowing a higher stocking rate in the high input treatment plots compared to the low input treatment plots. 
Lamb production per ha from both treatments was significantly lower in 2004 than 2003. We feel that this was due to the incidence of internal parasites in 2004. Ten` lambs and 3 ewes showed clinical symptoms of worm infestation between late June and August 2004 and were drenched with ivomectin. However, no similar symptoms were observed in 2003. Seven of the lambs drenched belonged to the high input treatment while 4 were from the low input treatment. Two of the three drenched ewes belonged to the high input treatment. This suggests that in situations where use of dewormers is restricted, such as in organic production, stocking rates should be lowered. 


\section{REFERENCES}

Agricultural Marketing Service. 2000. http://www.amsusda.govnop/NOP/standards/FullText.pdf. Verified on $11 / 15 / 04$.

Allen, J., M. Boal, and P. Doherty. 1998. Identifying and testing alternative parasiticides for use in production of organic lamb. Final report on the study of alternative parasiticides for organic lamb production. Organic Farming Research Foundation.

Arrington, R.M., and C. E. Pachek. 1981. Soil nutrient content of manures in an arid climate. In Livestock Waste; a Renewable Resource. American Society of Agricultural Engineers: 150-152. Soil Conservation Service, Phoenix, Arizona, USA.

Avery, D. T. 1998. The hidden dangers in organic food. Centre for Global Food Issues. http://www.cgfi/materials/articles/2002/jun-25-02.htm. Verified on 11/14/04.

Barger, I. A. 1997. The role of epidemiological knowledge and grazing management for helminth control in small ruminants. International Journal of Parasitology 29: 41-47.

Benkov, B. 1964. Effect of spring application of sheep dung on beard-grass pasture in the western Rhodopes. Rastenievudni Nauki 1: 115-124.

Buckley, K. E. 2004. Producing quality compost from livestock manure. http://www.engormix.com. Verified on 9/23/04.

Burgress, M. R., D. J. Barker, D. A. Mangione, R. M Sulc, S. K. Harrison, and D. L. Zartman. 2003. Financial analysis of three pasture types for meat goat production from grazing. Proceedings of AFGC conference, 2004. Roanoke, Virginia.

Burros, M. 1999. Eating well; Anti-organics, and flawed. Alternative Agricultural News. http://www.moscowfood.coop/organic3.html. Verified on 11/14/04.

Cabaret, J. 2002. Managing helminthes of ruminants in organic farming. Veterinary Research 33: 625-640.

Currl, M. L., R. J. Wilkins, R. W. Synaydon, and V.S. Shanmugalingam. 1985. The effect of stocking rate and nitrogen fertilizer on a perennial ryegrass-white clover sward. 2 subsequent sward and sheep performance. Grass and forage science 40: 141-149.

Curll, M.L., and R. J. Wilkins. 1981. The effect of treading and the return of excreta on a perennial ryegrass/white clover sward defoliated by continuously grazing sheep. 
Proceedings of the XIV International Grassland Congress held at, Kentucky, USA June 15-24, 1981.West View Press 450-458. Boulder Colorado, USA.

Corbet, T. L., and E. P. Furnival. 1976. Early weaning of grazing sheep. 2. Performance of ewes. Australian Journal of Experimental Agriculture and Animal Husbandry 16: 156-166.

Davis, G. H. 1975. Growth, fertility and wool production of young merino ewes fed different levels from 7 to 19 months of age. Proceedings of the New Zealand Society of Animal Production 35: 145-149.

Delate, K. 2003. Fundamentals Of Organic Farming. Iowa State University Extension Bulletin 7, 2003.

Durham, S. 2002. Making manure-borne pathogens stay put. Agricultural Research 10:9. Easterbrook, G. 1997. Forgotten benefactor of humanity. The Atlantic Monthly 1: 75-82. Economic Research Service. 2004. http://www.ers.usda.gov/Data/organic. Verified on 02/24/04.

Eghball, B., D. Giting, and J. E. Gilley. 2004. Residual effects of manure and compost application on corn production and soil properties. Agronomy Journal 96: 442-447.

Ely, D. G. 1994. The role of grazing sheep in sustainable agriculture. Sheep Research Journal, special issue: $37-51$.

Evanylo, G. K. 2004. Managing nitrogen in organic wastes. Proceedings of AFGC conference, 2004, Roanoke, Virginia.

FAO. 2004. Interdepartmental Working Group On Organic Agriculture. http://www.fao.org/organicag. Verified on 6/11/04.

Gaskell, M. 1999. Efficient use of organic nitrogen fertilizer sources. Organic Farming Research Foundation. Report, March 1, 1999.

Gilliam, J. W., T. J. Logan, and F. E. Broadbent. 1982. Fertilizer use in relation to the environment. Proceedings of the $184^{\text {th }}$ National Meeting of American Chemical Society. Division of Fertilizer and Soil Chemistry: 53.

Greene, C., and A. Kremen. 2003. US organic farming in 2000-2001: Adoption of certified systems. US Department of Agriculture, Economic Research Service, Resource Economics Division, Agriculture Information Bulletin No. 780: iii-iv.

Gorodnii, N. G. 1964. The effect of continued use of fertilizers on soil fertility and the yield of cotton and other crops. Agrokhimiya 8: 49-56. 
Howells, K., and C. Marley. 2001. Research on alternative approaches to parasite control. Elm Farm Research Bulletin No. 56, July, 2001.

Kandapola, C. S. 2002. Effects of nitrogen fertilizer and red clover (Trifolium pretense L.) component on productivity of grass-legume mixed swards. Thesis, College of Agriculture, Forestry and Consumer sciences, West Virginia University.

Kumm, K. 2002. Sustainability of organic meat production under Swedish conditions. Agriculture, Ecosystems and Environment 88: 95-101.

Keatinge, R. 2004. Organic livestock production in the hills and uplands. ADAS Redesdale, Otterburn publication. http://www.bsas.org.uk/meetings/annalproc/Pdf2003/237.pdf. Verified on $11 / 14 / 04$

Killeen, J. A. 2000. Compost research on a Wisconsin organic farm. Biocycle 41: 54-57.

Kirk, J. H. 2004. Pathogens in manure. http://www.vetmed.ucdavis.edu/vetext/INF-DA/pathogmanure.pdf. Verified on 9/23/04.

Kuo, S., and A. S. Baker. 1982. The effect of soil drainage on phosphorus status and availability to corn in long-term manure amended soil. Soil Science Society of America Journal 46: 744-747.

Kyle, B. 2004. Totally organic lamb. Ontario Sheep News Articles. http://wwwontariosheep.org/ontsheepnewsart0016.htm. Verified on 6/11/04.

Laissus, R., and D. Leconte. 1982. Consequence of application of cattle slurry on a grazed permanent pasture. Fourrages 89: 63-72.

Lewis, K. H. C., and A. N. Cullen. 1973. Lamb growth on long and short grazed pastures of ryegrass or Timothy/cocksfoot. Proceedings of the New Zealand Grassland Association 34: 199-204.

Lipson, M. 1997. Searching for the "O-word": Analyzing the USDA Current Research Information System for pertinence to organic farming. http://ofrf.org/publications/oword/exsum.html. Verified on 08/23/04.

Lotter, D. 2001. Organic agriculture. Journal of Sustainable Agriculture 21: 59-127.

Mader, P., A. Fließbach, D. Dubois, L. Gunst, P. Fried, and U. Niggli . 2002. Soil fertility and diversity in organic farming. Science 296:1694-1697. 
Mangan, F., A. Barker, S. Bodine, and P. Borten. 2000. Compost use and soil fertility. http://www.umassvegetable.org/newsletters/archive/2000/2000_11.html. Verified on $11 / 13 / 04$.

Mark, B., W. Brinton, S. Frank, J. West, T. Wayne, and C. Mathew. 2004. The CCQC Maturity Index. http://wwwoardc.ohio-state.edu/michel/compostquality.htm. Verified on 9/23/04.

Marriott, C. A., and I. J. Gordon. 1990. Extensification of sheep grazing systems; Effects on soil nutrients, species composition and animal production. Macaulay Land Use Research Institute, Craigiebuckler, Aberdeen.UK.

McNeill, J. R., and V. Weiniwarter. 2004. Breaking the sod: humankind, history, and soil. Science 304: 1627-1629.

Murzynski, J. 1971. The effect of varying fertilizing and utilization on the yield and growth of a pasture at the Agricultural Experimental station, Pawlowice. Zeszyty Naukowe Wyzszej Szkoly Rolniczij W Wroclawiu. Rolnictwo 28: 169-192.

Murphy, W. M., A. D. Menabarreto, J. P. Silman, and D. L. Dindal. 1995. Cattle and sheep grazing effects on soil organisms, fertility and compaction in a smooth-stalked meadowgrass-dominant white clover sward. Grass and Forage Science J.50: 191-194.

National Research Council. 1989. Alternative Agriculture. National Academy Press, Washington, D.C. 1989. PP 89.

Nesheim, L., B. C. Boller, J. Lehmann, and U. Walther. 1990. The effect of nitrogen in cattle slurry and mineral fertilizers on nitrogen fixation by white clover. Grass and Forage Science 45: 91-97.

Outhouse, J. B. 2004. Managing and utilizing pasture and harvested forages for sheep. Purdue Forage Information. http://www.agry.purdue.edu/ext/forages/publications/ID-153.htm. Verified on 6/11/04.

Olson, M. E. 2004. Human and animal pathogens in manure. http://www.gov.mb.ca/agriculture/livestock/papers/olson.pdf. Verified on 9/23/04.

Oltjen, J. W., and J. L. Beckett. 1996. Role of ruminant livestock in sustainable agricultural systems. Journal of Animal Science 74: 1406-1409.

Pell, A. N. 1997. Manure and microbes: Public and animal health problem? Journal of Dairy Science 80: 2673-2681. 
Pflimlin, A., B. Hubert, and D. Leaver. 2001. Grazing: Present importance and new concerns. Fourrages 166: 117-135.

Philipps, L. 2001. Elm Farm Research Bulletin No. 56, July, 2001.

Qubain, F. I. 1994. Lamb production for ethnic consumers in the USA. North Carolina Shepherds Symposium December 3, 1994.

Rayburn, E. B., and S. B. Rayburn. 1998. A standardized plate meter for estimating pasture mass in on-farm research trials. Agronomy Journal 90: 241.

Richardson, A. 1999. New Zealand "at the organic crossroads". http://www.avalonorganic.co.nz/Avalon/NZAOC95.doc. Verified on 1/14/05.

Richardson, A., and K. Scholar. 1997. The potential for commercial organic sheep farming in south Island. http://www.dpl.gld.gov.au/business/154.html. Verified on 11/19/04.

Ruffner, J. A. 1980. Climate of the States.Vol. 2: 833.

Rich. D. K. 2003. Organic research just beginning. San Francisco Chronicle. http://www.ofrf.org/press\%20clippings/SFChronicle.102503.Lipson.pdf. Verified on $11 / 15 / 04$.

SAS Institute. 1990. SAS user's guide: Statistics 1990. SAS Inst., Cary. NC.

Steinshamn, H. 2001. Effect of cattle slurry on the growth potential and clover proportion of organically managed grass-clover leys. Soil and Plant Science 51: 113-124.

Steinwender, R., L. Gruber, A. Schauer, T. Guggenberger, J. Hausler, and M. Sobotik. 2000. Comparison of organic and conventional farming on a grassland farm. $1^{\text {st }}$ communication: grassland yield, forage feed value, and amount of slurry. Bodenkultur 51:267-281.

Strauch, D, A. Moosmuller, U. Kandler, W. konig, and W. Philipp. 1982. Preliminary results of investigations on the composition and hygienic condition of organic and organo-mineral fertilizers. Landwirtschaftliche Forschung 35: 55-65.

Suckling, F. E. T. 1975. Pasture management trials on unploughable hill at Te Awa. 3. Results for 1959-1969. New Zealand Journal of Experimental Agriculture 3: 351-436.

Tritschler, J. 2003. Internal parasite control in grazing ruminants. Virginia State University publication. http://www.uwex.edu/ces/animalscience/sheep/wisline_03/parasite_control.pdf. Verified on $1 / 14 / 05$. 
Tyler, M., S. Diddy, J. St. Germain, S. Lombard, and D. Nightingale. 1994. Solid waste services program. State of Washington, Department of Ecology. Publication No. 94-38.

Umberger, S. H. 2001. Sheep grazing management. Virginia Cooperative Extension publication Bulletin 410-366.

Vetter, A., and K. Z., Klasink. 1972. Limits to the use of pig and poultry slurries. Landwirtschaftliche Forschung Sonderheft 22: 122-134.

Warner, J. R., and S. H. Sharrow. 1984. Set stocking, rotational grazing and forward rotational grazing by sheep on western Oregon hill pasture. Grass and Forage Science 39: 331-338.

Weller, R. F., and A. Cooper. 2002. Seasonal changes in the crude protein concentration of mixed swards of white clover/perennial ryegrass grown without fertilizer $\mathrm{N}$ in an organic farming system in United Kingdom. Grass and Forage Science 56: 92-95.

Wells, A., and L. Gegner. 2000. Sustainable Sheep Production. ATTRA—National Sustainable Agriculture Information Service. 